\title{
Türkiye'de Finansal Gelişme ve Enerji Tüketiminin Ekonomik Büyüme Üzerindeki Etkisi: Yapısal Kırılmalı Bir Analiz ${ }^{1}$
}

\author{
Hüseyin USLU²
}

Öz

Bu çalışmada; finansal gelişme ve enerji tüketiminin ekonomik büyüme üzerindeki etkileri, Türkiye'nin 1960-2019 dönemi verileri kullanılarak incelenmiştir. Serilerin durağanlığ1; Vogelsang-Perron (1998), Lee-Strazicich (2003) ve Carrion-iSilvestre vd. (2009) birim kök testleriyle incelenmiş, serilerin I(1) oldukları görülmüş̧ür. Serilerin eşbütünleşme durumu; Gregory-Hansen (1996) ve Maki (2012) testleriyle incelenmiş, serilerin eşbütünleşik oldukları bulunmuştur. Uzun dönem analizleri; FMOLS, DOLS ve CCR yöntemleriyle gerçekleştirilmiş, ekonomik büyümenin; kredi miktar1 \%1 arttığında ortalama $\% 0,13$, para arz1 $\% 1$ arttığında $\% 0,13$ ile $\% 0,24$ arasında, enerji tüketimi $\% 1$ arttığındaysa ortalama $\% 0,40$ arttığ1 belirlenmiștir. Kısa dönem analizleri de FMOLS, DOLS ve CCR yöntemleriyle gerçekleștirilmiș ve özel sektöre verilen kredilerin ekonomik büyümeyi kısa dönemde de artırdığı, ancak bu etkinin uzun dönemdekinden daha küçük olduğu belirlenmiştir. Para arzındaki artışların ekonomik büyüme üzerindeki kısa dönemli etkilerinin de pozitif olduğu görülmüştür. Enerji tüketiminin ise ekonomik büyümeyi kısa dönemde, uzun dönemdekinden daha fazla artırdığı tespit edilmiştir. Seriler arasındaki nedensellik ilişkileri VECM yöntemiyle incelenmiş, ekonomik büyümeden enerji tüketimi ve para arzına doğru tek yönlü, kredi hacminden enerji tüketimi ve para arzına doğru tek yönlü, enerji tüketimi ile para arzı arasında iki yönlü uzun dönem nedensellik ilişkilerinin var olduğu bulunmuştur. Ayrıca kredi hacminden enerji tüketimine doğru tek yönlü, enerji tüketimi ile para arazı arasında iki yönlü kısa dönemli nedensellik ilişkileri belirlenmiştir.

Anabtar Kelimeler: Finansal Gelişme, Enerji Tüketimi, Ekonomik Büyüme, Yapısal Kırılmalı Zaman Serisi Analizleri, VECM Nedensellik Testi

\section{The Impact of Financial Development and Energy Consumption on Economic Growth in Turkey: An Analysis with Structural Breaks}

\begin{abstract}
The aim of this study is to theoretically and empirically analyze the impacts of financial development and energy consumption on economic growth in Turkey's 1960-2019 period. In this context structural break analyses are conducted. Stationarity of the series is analyzed by Vogelsang and Perron (1998), Lee and Strazicich (2003) and Carrion-i-Silvestre et al. (2009) unit root tests and all the series are determined to be I. (1). Existence of cointegration relationship between the series in the models is investigated by Gregory and Hansen (1996) and Maki (2012) cointegration tests and it is decided that there exists cointegration relationship between the series in the models. Long run analyses are carried out by FMOLS, DOLS and CCR methods and it is determined that $1 \%$ increase in credit used by private sector, broad money supply and energy consumption raise economic growth by $0,13 \%, 0,13-0,24 \%$ and $0,40 \%$, respectively. Causality relationships between the series are analyzed by VECM method and it is found that there is one way causality from economic growth to energy consumption and money supply, one way causality from credit volume to energy consumption and money supply and two way causality between energy. On the other hand, one way causality from credit volume to energy consumption and two way causality between energy consumption and money supply are determined in the short run in Turkey for the same period.
\end{abstract}

Key Words: Financial development, Energy Consumption, Economic Growth, Time Series Analysis with Satuctural Breaks, VECM Causality Test

\section{Atıf İçin / Please Cite As:}

Uslu, H. (2022). Türkiye’de finansal gelişme ve enerji tüketiminin ekonomik büyüme üzerindeki etkisi: yapısal kırılmalı bir analiz. Manas Sosyal Arastırmalar Dergisi, 11(1), 188-217.

Geliş Tarihi / Received Date: 21.03.2021

Kabul Tarihi / Accepted Date: 28.06.2021

\footnotetext{
1 Bu çalışma, yazarın Osmaniye Korkut Ata Üniversitesi, Sosyal Bilimler Enstitüsü, İşletme Anabilim Dalında 13/07/2020 tarihinde sunulan "Türkiye'de Finansal Gelisme ve Enerji Tüketiminin Ekonomik Büyüme Üzerindeki Etkisi" adlı yüksek lisans tezinden türetilmiştir.

2 Süleyman Demirel Üniversitesi, İktisadi ve İdari Bilimler Fakültesi, Ekonometri Bölümü, h.uslu80@hotmail.com,

(D) ORCID: 0000-0002-2642-1175
} 


\section{Giriş}

Ekonomik büyüme ve refah artışı bütün ülkelerin en temel hedeflerindendir. Bu hedefe hangi yollarla ulaşılabileceği; ülkelerin sahip oldukları üretim faktörlerinin miktarına, uygulamakta oldukları döviz kuru, faiz ve dış ticaret politikalarına, yönetim biçimlerine, jeopolitik konumlarına ve dahil oldukları ekonomik ve siyasi birliklere göre değişiklik gösterebilmektedir. Adam Smith (1776) ile başlayan Klasik İktisat Teorisinde; serbest dış ticaret, işbölümü ve uzmanlaşma, ekonomik büyümenin en önemli kaynakları olarak gösterilirken, Solow (1956) ve Swan (1956) öncülüğünde geliştirilen Neo-Klasik Büyüme Teorisinde; yurtiçi tasarrufların ve sabit sermaye oluşumunun ekonomik büyüme üzerindeki etkilerine dikkat çekilmiştir. Romer (1986) ve Lucas (1988) ile başlayan İçsel Büyüme Modelinde ise; beşeri sermaye, araştırma ve geliştirme (Ar\&Ge) faaliyetleri ve teknolojik ilerleme, ekonomik büyümenin temel dinamikleri olarak kabul edilmiştir.

Finansal gelişme, ekonomik büyüme için gerekli yatırım ve tüketim harcamalarının finansmanında önemli bir yere sahiptir. Türkiye, 24 Ocak 1980 İstikrar Kararları ile ticari, 11 Ağustos 1989 tarih ve 32 sayılı Türk Parasının Kiymetini Koruma Hakkında Karar ile de finansal liberalizasyon sürecini tamamlamıştır (Kılıç, 2012, s. 133). Böylece 3 Ocak 1986'da faaliyete giren İstanbul Menkul Kiymetler Borsası'nda ve Türkiye'deki bankalarda yabancı yatırımcıların da işlem yapabilmelerinin ve elde ettikleri kâr ve anaparalarını yurtdışına serbestçe transfer edebilmelerinin önü açılmıştır. Bu şekilde ülkeye daha fazla yabancı sermaye gelmesi, yurtiçi yatırım ve tüketim faaliyetlerinin ve ekonomik büyümenin hızlanmasına katk1 sağlamıştır. Özellikle 2002 y1l sonrası dönemde yürütülen özelleştirme faaliyeteleri kapsamında Türkiye'ye gelen yabanc1 sermaye yatırımları, 2003-2007 döneminde ekonomik büyümenin ortalama \%7,2'ye ulaşmasını sağlamıştır (EVDS, 2019a). 2001 bankacılık ve döviz krizinde Türkiye'de faaliyet gösteren 25 banka faaliyetlerine son vermiş, finansal piyasalar önemli ölçüde daralmıştır. Ancak 15 Nisan 2001'de yürürlüğe giren Güçlü Ekonomiye Geçiş Programı ile Bankacıllk Denetleme ve Düzenleme Kurulunun (BDDK) görev ve sorunluluklarının artırılması ve Türkiye Cumhuriyet Merkez Bankasının (TCMB) tam bağımsız hale getirilmesi ile finansal piyasalarda tekrar istikrar sağlanmış ve ülke hızlı bir ekonomik büyüme sürecine girmiştir (Şamiloğlu, 2007, s. 5-6).

Öte yandan enerji tüketimi de günümüzde ekonomik büyümenin hem bir gereği, hem de bir sonucu haline gelmiş olup, bilim insanları bu alanda önemli çalışmalar yapmaktadırlar. Simon Kuznets (1955) tarafindan gündeme getirilen; kişi başına düşen reel milli gelir ile bireyler arasındaki reel gelir eşitsizliği arasında gözlemlenen ters U şeklindeki ilişki Grossman ve Krueger (1995) tarafından kişi başına düşen reel milli gelir ile kişi başına düşen karbondioksit $\left(\mathrm{CO}_{2}\right)$ salınımı arasındaki ilişkiye uyarlanmış ve buna Çevresel Kuznets Eğrisi adı verilmiştir. Bu teoriye göre; ekonomik büyüme (ya da kişi başına düşen reel milli gelir) artarken, önce çok enerji kullanılacak ve çevre çok kirletilecek, sonra artan gelir, çevre bilinci ve ilerleyen teknolojik olanaklar sayesinde çevre kirliliği azalmaya başlayacaktır (Lebe, 2016, s. 178). Beckerman (1992), Grossman ve Krueger (1995) ve Janicke, Binder ve Mönch (1997) ekonomik büyümenin daha fazla artırllabilmesi için çok daha fazla enerji tüketimine gereksinim duyulduğunu, bunun da tekrar çevre kirlenmesine neden olarak S (veya ters $\mathrm{N}$ ) şeklinde bir Çevresel Kuznets Eğrisi oluşmasına yol açacağını ifade etmişlerdir.

Görüldüğü üzere; ülkeler açısından sürdürülebilir ve yüksek bir ekonomik büyüme düzeyi yakalanabilmesi için finansal gelişme ve enerji tüketimi oldukça önemli bir yere sahiptir. Literatürde genellikle finansal gelişme ve enerji tüketiminin ekonomik büyüme üzerindeki etkileri ayrı ayrı analiz edilirken, Tutgun (2019)'da olduğu gibi bu çalışmada da bu değişkenler bir arada analize dâhil edilecektir. $\mathrm{Bu}$ yolla; ekonomik büyümeyi etkileyen reel ve nominal değişkenler bir arada kullanılarak, Klasik İktisatçıların dışladığı nominal değişken (finansal gelişme) ile Monetaristlerin ikinci plana attıkları reel faktörler (enerji tüketimi) aynı anda dikkate alınmıs olacaktır.

Bu çalşşmada; ekonomik büyüme açısından büyük öneme sahip finansal gelişmeyi ve enerji kullanımı ile ekonomik büyüme arasındaki ilişkiler, teorik ve uygulamalı ekonometrik olarak detaylı biçimde analiz edilecektir. Özelliklede, Mart 2020'den beri dünya gündemini meşgul eden Covid-19 salgını ile birlikte, ülkelerin üretim seviyelerinin ve buna bağlı olarak petrol taleplerinin düşmesinin petrol fiyatları üzerinde yarattığı derin şok da göstermektedir ki bu konu, ülke ve dünya ekonomisi açısından güncel ve önemlidir. $\mathrm{Bu}$ yönleriyle de çalışmanın, literatüre ve ülke ekonomisine bir katkı sağlaması beklenmektedir.

Çalışmasının amacı; Türkiye'de finansal gelişme ve enerji tüketiminin, ekonomik büyüme üzerindeki etkilerini teorik ve ampirik olarak incelemektir. Bu kapsamda, Türkiye'nin 1960-2019 dönemi yılllk 
verilerinden yararlanılmıştır. Çalışma beş bölümden oluşacak olup, birinci bölümde; finansal gelişme, enerji tüketimi ve ekonomik büyümenin teorik çerçevesi verilecek, ikinci bölümde; Türkiye ekonomisinde ekonomik büyüme, finansal gelişme ve enerji tüketimi grafikler yardımıyla incelenecek, üçüncü bölümde; ampirik literatür taraması sonuçları sunulacak, dördüncü bölümde; ampirik analizlerde kullanılacak veri seti ve ampirik model verilecek, beşinci bölümde; ampirik yöntem ve bulgulara yer verilerek analizler gerçekleştirilecektir. Sonuç ve değerlendirmeler ile çalışma tamamlanacaktır.

\section{Finansal Gelişme, Enerji Tüketimi ve Ekonomik Büyüme: Teorik Çerçeve}

\section{Finansal Gelişme}

Finansal sistem; fon fazlasına sahip olan kişi ya da kurumlar ile fon talebi bulunan kişi ve kurumlar arasındaki fon değişiminin, belirli kurumlar aracilığıla, çeşitli yatırım ve finansman araçları kullanılarak, belirli bir hukuksal ve yönetsel düzen içinde gerçekleştirildiği sistemdir (Finansalgoz, 2017). Oğuz ve Canan (2016) finansal sistemi; fon arz edenler ile fon talep edenler arasındaki iletişimi, belirli çıkar beklentileri karşılığında olanaklı kılan mekanizma olarak tanımlamaktadır. Mankiw (2010) ise finansal sistemi; geliri olup da tasarruf amacıyla borç vermek isteyenler ile kârlı yatırımlarını gerçekleștirebilmek için borç almak isteyenler arasındaki, kanuni ve kurumsal aracılık hizmetleri olarak tanımlamaktadır. Finansal sistem bir bütün olarak birçok araç, kurum ve piyasanın bir araya gelmesiyle oluşmaktadır. Finansal kurumlar arasında; borsalar, bankalar, sigorta şirketleri, bankerler ve hatta tefeciler de sayılabilirken, finansal araçlar arasında; bozuk (madeni) para, banknot (kağıt para), tahvil, hisse senedi, swap, VİOP (Vadeli İşlemler Opsiyon Piyasası), forex (Foreign Exchange Market; Döviz İsslemleri Piyasası) gibi türev ürünler ve kripto paralar sayılabilir (TCMB, 2015a).

Finansal sistemin ve bu sistem içinde yer alan kurumların temel görevleri; fon arz edeceklerle, fon talebi olanlar arasında aracılık yapmaktır. Bu sistem sayesinde, finansal kaynakların dağılımında ekonomik etkinliğe ulaşılır (Merton ve Bodie, 1995, s. 32-33). Finansal sistemin başlıca fonksiyonları arasında; finansal varlıkların el değiştirmesine aracılık ederek fon piyasasında dengenin sağlanmasına yardım etmek, risk dağılımı ve tasarruf birikimi sistemlerini oluşturup, tasarruflar arasındaki vade ve miktar uyumsuzluğu sorununu ortadan kaldırıp, küçük çaplı birikimleri bir araya getirip, büyük çaplı projelerin hayata geçmesine olanak sağlamak ve bu arada mülkiyetin tabana yayılmasını sağlamak, finans sisteminde gerekli garantörlük ve güven ortamını tesis ederek, kaldıraçlı işlemlere imkân sağlayıp, bu yolla küçük birikimlerle, büyük finansal işlemlerin gerçekleştirilebilmesine olanak sağlamak, finansal kaynakların bölgeler ve sektörler arasında yer değiştirebilmesine olanak sağlayarak, zaman içinde kaynak dağılım etkinliğinin sağlanmasına katkıda bulunmak, finansal varlıklara likidite kazandırmak, risk yönetimi ve kontrolü için gerekli yöntemleri geliştirmek ve finansal ürünlerin fiyatları konusunda asimetrik bilgi sorununu ortadan kaldırarak, tam rekabet piyasasının oluşmasına katkı sağlamak sayılabilir (Er, 2011, s. 308).

Finansal sistemin bu fonksiyonlarını yerine getirmesi, ülkelerdeki tasarruf ve yatırımları artırarak, ekonomik büyüme ve kalkınmayı destekleyecektir. Bunun için ülkelerin finansal yönden gelişmiş olmaları gerekmektedir. Finansal gelişme; finansal aracı kurumların, finansal piyasaların ve finansal araçların gelişmesi, çeşitlenmesi ve finans piyasasının işlem hacminin büyümesi biçiminde tanımlanabilmektedir (Özcan ve Ar1, 2011, s. 122). Furstenberg ve Fratianni (1996)'ye göre; yurtiçi üretim ve tüketim faaliyetlerini yerel kaynaklarla finanse etmekten çıkıp, dış kaynakların da kullanılmaya başlanması, finansal kurumların ve aracilık faaliyetlerinin gelişmesi, kredi kaynaklarına doğrudan erişilebilmesi yönünde piyasaların gelişmesi, uluslararası sermaye piyasalarına kolay erişim, mevduat faizleri ile kredi faizleri arasındaki marjın daralması, bir ülkedeki finansal sistemin geliştiğini ve derinleştiğini göstermektedir. Finansal gelişmenin genel olarak tasarrufları harekete geçireceği, riski bölüştüreceği ve ekonomik büyümeyi destekleyeceği kabul edilmektedir (Bozoklu ve Yllanc1, 2013, s. 163). Schumpeter (1911), finansal gelişmenin ekonomik büyümeyi olumlu yönde etkileyeceğini ifade ederken, Robinson (1952), ekonomik büyümenin finansal gelişmeyi etkileyeceğini belirtmiştir.

\section{Enerji Tüketimi}

Ülkelerin ekonomik olarak büyüyebilmesi ${ }^{3}$ ve kalkınabilmesi ${ }^{4}$ açısından, yeterli ve sürekli miktarda ve uygun fiyatlarla enerjiye erişim büyük önem taşımaktadır. Enerji; iş yapabilme yeteneğini ve bir nesnenin

\footnotetext{
${ }^{3}$ Ekonomik büyüme; bir ülkenin sınırları içinde, belirli bir dönemde, son kullanıcılar için üretilen tüm mal ve hizmet miktarındaki artmayı ifade etmektedir (Mankiw, 2010, s. 20-22). Bu tanımım yanında, (Kitov, 2006; Jones, 2001 ve Peterson, 2017) araştırmacılar ise ekonomik büyümeyi; kişi başına düşen reel GSYH kullanılarak ölçülmesinin daha doğru olduğunu düşünenmektedirler.
} 
kendisine gösterilen dirence karşı hareketini ifade etmekte (Albayrak, 2019, s. 22) olup, Gültekin (2015, s. 2) enerjiyi; madde ve maddeler sisteminin iş yapabilme yeteneği ve birçok üretim aracının temel girdisi olarak tanımlamaktadır. Türk Dil Kurumu enerji için; maddede var olan ve 1sı veya ışık şeklinde ortaya çıkan güç tanımlamasını yapmaktadır (TDK, 2019). Yamak (2006, s. 3) enerjinin; potansiyel, kinetik, mekanik, elektrik, manyetik, termal ve kimyasal enerji şeklinde birçok farklı türde olabildiğini ve bu çeşitler arasındaki geçişlerin de mümkün olduğunu ifade etmiştir. Enerji tüketimi, var olan bir enerji türünün mal veya hizmet üretimi, ulaşım, iklimlendirme, aydınlatma veya başka amaçlarla kullanılmasını ifade etmektedir (NEED, 2018, s. 45). Enerji tüketiminde dikkat edilmesi gereken nokta; k1t bir kaynak olan enerjinin, mümkün olduğunca etkin kullanılmasıdır. Dünya çapında enerji tüketimi; buharlı makinelerin icadı sonrasında odun ve kömür tüketimi ile başlamış olup, 20. yüzyılın başlarında petrol kaynaklı sıvı yakıtların kullanılmaya başlanması ve sonrasında doğal gazın keşfi ve günlük hayatta yaygın kullanılmaya başlanmasıyla birlikte hızla artmıştır (Doğanay ve Coşkun, 2017, s. 1-2). Enerji, ülkelerin sosyal ve ekonomik ilerlemelerinin önemli bir girdisi olup, nüfusun artışı, kentleşme ve sanayileşmedeki artışların yanında, küreselleşme sonucunda artan üretim ve ticaret hacmine de bağll, doğal kaynaklara ve enerjiye olan ihtiyaç günden güne yükselmektedir (Sarıbaş, 2015, s. 7).

Enerji tüketim miktarları; genel olarak üretilen ve piyasaya arz edilen enerji kaynaklarının enerji değerleri üzerinden hesaplanır. Üretilen bu enerjinin belirli bir kısmı, iletim hatlarındaki kayıp/direnç olarak düşüldükten sonra, geri kalan kısım, ilgili ekonominin enerji talebi olarak belirlenir (Karakoç, Erbay ve Aras, 2011, s. 24-26). Enerji talebinin doğru öngörülmesi ve buna göre gerekli altyap1 ve üstyap1 çalışmalarının zamanında yürütülebilmesi açısından, enerji tüketiminin düzenli olarak ölçülmesinde yarar vardır. Ayrıca; enerji verimliliğinin doğru tespiti açısından da ekonomide kullanılan enerji miktarı ve bu enerji ile üretilen mal ve hizmet miktarının doğru biçimde ölçülmesi gerekmektedir (Çapın ve Söylem, 2017, s. 1). Enerij, üretim ve ulaştırmanın en temel girdilerinden olup, enerjiye uygun fiyatlarla ve bolca erişilebilmesi, ekonomik büyümeyi hızlandıracaktır. Günümüzde büyük bir öneme sahip olan enerji, sosyal refahın ve ekonomik büyümenin öncü göstergelerinden biri olarak kabul edilmektedir (Gülay, 2008, s. 1). $\mathrm{Bu}$ nedenle günümüze kadar süregelen toplumların/devletlerin önemli amaçlarından biri de enerji kaynaklarına sahip olabilmektir (Cihan, 2019, s. 3).

\section{Ekonomik Büyüme}

İnsanlık tarihi boyunca bireyler ve yöneticiler, kendi refahlarını ve içinde yaşadıkları toplumun refahını artırmayı, içgüdüsel bir dürtüyle sürekli öncelemişlerdir. Bu yolda gerek sözlü gerekse yazılı pek çok ilke, töre, anlaşma, hipotez ve teori geliştirilmiştir. 16-17. yy'da etkili olan Merkantilistler; ulusal gücün dış ticaret fazlasıyla artacağına inanmışlar, bunun için de devletin ekonomiye müdahale ederek ithalatı kısıtlamasını ve böylece ülkedeki altın ve gümüş gibi değerli varlıkların yurtdışına çıkmasının engellenmesini, devletin ihracatı teşvik ederek ülkeye daha fazla altın ve gümüş girmesini sağlanması gerektiğini savunmuşlardır (Peker, 2015, s. 3). Fransa'da ortaya çıkan ve 1752-1776 döneminde etkili olan Fizyokrasi akımı ise; doğanın düzeninden hareketle, tarımsal üretimin önemini dile getirmiş, ekonomik büyümenin kaynağını tarımsal üretimde görmüş, serbest üretim ve dış ticareti savunmuşlardır (Avc1, 2018, s. 8-10). Dr. François Quesnay (1694-1774) tarafından teorik çerçevesi oluşturulan bu akımda; bireysel girişimcilere daha fazla özgürlük verilmesi, devletin ekonomiye gereksiz müdahalelerden kaçınması ön plana çıkarılmıştır. Kendilerinden sonra gelecek olan Adam Smith'i (1723-1790) de etkileyecek olan "laissez. faire, laissez passer (birakın yapsınlar, bırakmı gecsinler)" görüşünün sahibidirler (Torun, 2003, s. 188). Buradaki "birakım ₹ yapsınlar" serbest girişimciliği ve üretimi, "bırakımı gęsinler" serbest diş ticareti ifade etmektedir (Aydın, 2003, s. 1-2).

Klasik İktisat Teorisi, A. Smith'in (1776) yllında yayınlanan "Milletlerin Zenginliüinin Doğası ve Nedenleri Üzerine Bir Inceleme (An Inquiry into the Nature and Causes of the Wealth of Nations)" adlı eseriyle başlamıs,, 1936'da J. Maynard Keynes'in 'İstibdam, Faiz ve Paramn Genel Teorisi (The General Theory of Employment, Interest and Money)" adlı eserinin yayınlanmasına kadar etkili olmuştur. Genel olarak; devletlerin ekonomiye müdahale etmemeleri gerektiğini (serbest piyasa ekonomisi, liberalizmi) savunan Klasik İktisatçlar, ekonomide dengeden bir sapma meydana geldiğinde, bunun devlet müdahalesine ihtiyaç duyulmaksızın,

\footnotetext{
${ }^{4}$ Ekonomik kalkınma ya da gelişmişlik düzeyi; ekonomik büyüme ile elde edilen gelirin bütün toplum katmanları arasında dengeli bir şekilde dağıtılmasını, halkın kolayca erişebileceği şekilde eğitim, sağlık, adalet ve güvenlik hizmetlerinin, altyap1 ve üstyap1 tesislerinin sunulmasını ifade etmektedir (Taban ve Kar, 2016, s. 4). Enerji tüketimi, refahın bir ölçütü olan GSYH ile paralellik göstermektedir. Dünya GSYH'sinden fazla pay alan gelişmiş ülkelerin, enerji tüketimindeki paylarının da daha fazla olduğu görülmektedir (Saatçioğlu ve Küçükaksoy, 2004, s. 4).
} 
kendiliğinden tekrar sağlanacağını iddia etmişlerdir. Bu tezlerine gerekçe olarak da ekonomide ücretlerin ve fiyatların tam esnek olduğunu göstermişlerdir. Klasik iktisatçılar özellikle fiyata özel bir önem verirler ve buna "Görünmez El (Invisible Hand)" adını verirler. Yani fiyatlar, ekonomik dengeyi sağlayan görünmez güçtür. Klasik İktisatçılar aynı zamanda denk bütçe varsayımını da benimserler ve kamu bütçesinin açık ya da fazla vermemesinin daha doğru olduğunu ifade ederler. Klasiklere göre devlet sadece; piyasaların etkin işlemesini sağlamaya yönelik düzenlemeleri yapmalı, adalet ve savunma gibi temel hakları garanti altına almalıdır. Bunun haricinde üretim ve işgücü piyasalarına bir aktör olarak dâhil olmamalıdır (Harris, 2007, s. 1-4).

Keynes (1936) ekonomide önemli olanın arz değil, talep olduğunu, özellikle ekonomik kriz dönemlerinde hükumetlerin, bütçe açığı verme pahasına genişletici maliye politikaları uygulayarak, ekonomik dengenin yeniden kurulmasına yardım etmelerinin gerektiğini savunmuştur. Harrod (1937, 1939) ve Domar (1946, 1947) çalışmalarıyla geliştirilen Post Keynesyen Ekonomik Büyüme Modelinde; Keynes'in geliştirmiş olduğu kısa dönemli statik büyüme modeli eleştirilmiş, uzun dönemli ve dinamik bir büyüme modeline dönüştürmüştür. Teknoloji dışsal olarak kabul edip, ekonomik büyümeyi yatırımlar (ve dolayısıyla tasarruflar) üzerinden açıklamaya çalş̧an Harrod-Domar Ekonomik Büyüme Modeli için ekonomide çarpan (hızlandıran) katsayısı önemli bir rol oynamaktadır. Bu modelde tasarruflar $(S)$, milli gelirin $(Y)$ bir fonksiyonudur:

$S=s Y$

Burada $s$; marjinal tasarruf eğilimini göstermektedir. Harrod (1939) bu tasarrufun, planlanan tasarruf $\left(S_{p}\right)$ olduğunu ve tam istihdama sahip bir ekonomide bunun mutlaka gerçekleşen tasarrufa $\left(S_{f}\right)$ eşit olacağını ifade etmiştir.

$S_{p}=S_{f}$

$\mathrm{Bu}$ modelde planlanan yatırımların, planlanan tasarruf, fiili tasarruf ve fili yatırım gibi faktörlerden bağımsız olduğu kabul edilir. Bu nedenle, planlanan yatırımlar ile planlanan tasarrufların her zaman eşit olması beklenemez. Bu durumun nedeni; yatırımı yapacak karar birimleri ile tasarrufları gerçekleştirecek karar birimlerinin farklı olmasıdır (Kızılkaya, 2017, s. 6-7). Harrod-Domar Ekonomik Büyüme Modelinde önem verilen hızlandıran katsayısı $(g)$, sermaye miktarında meydana gelen değişimin, üretimde meydana gelen değişime oranı şeklinde hesaplanmakta olup, zaman içinde sabit olduğu kabul edilir:

$g=\frac{\Delta K}{\Delta Y}$

Bu katsayıya Türkçe iktisat literatüründe Sermaye Hâsıla Katsayısı adı da verilmekte olup, çıktıy1 1 birim artırabilmek için sermayenin kaç birim artırlması gerektiğini de göstermektedir. Denklem (3)'te küçük bir düzenleme yapılarak, planlanan yatırımlar $\left(I_{p}\right)$ aşağıdaki şekilde hesaplanabilir:

$I_{p}=g\left(Y_{t}-Y_{t-1}\right)$

Harrod-Domar Ekonomik Büyüme Modelinde planlanan yatırımlarla, planlanan tasarrufları eşitleyen büyüme hızı, uygun (gerekli) büyüme hızı olarak isimlendirilir ve aşağıdaki şekilde hesaplanır.

$S_{p}=I_{p}$

$s Y_{t}=g\left(Y_{t}-Y_{t-1}\right)$

Buradan gerekli büyüme hızı:

$G_{w}=\frac{Y_{t}-Y_{t-1}}{Y_{t-1}}=\frac{s}{g}$

şeklinde elde edilir. Bu oran, yatırımların kapasite artırıcı etkisiyle, talep uyarıcı etkisini eşitleyen büyüme oranıdır. Harrod-Domar Ekonomik Büyüme Modelinde doğal büyüme oranı $\left(G_{n}\right)$; nüfus artış hızı $(n)$ ve teknolojik ilerleme hızının $(t)$ toplamına eşit olarak alınmaktadır.

$G_{n}=n+t$

Bu modelde kamu harcamaları yoktur. Ekonomi dışa kapalıdır ya da dış faktörlerin ekonomik aktiviteler üzerinde anlamlı bir etkisi yoktur. Harrod-Domar Ekonomik Büyüme Modelinde ekonomi her zaman tam istihdamda dengededir. 
Robert Solow (1956) ve Trevor Swan (1956) çalışmalarıyla geliştirilen ve literatürde kısaca SolowSwan (1956) şeklinde ifade edilen Neo-Klasik Ekonomik Büyüme Modeli, teknolojiyi dışsal olarak kabul ettiği için Dışsal Ekonomik Büyüme Modeli olarak da anılmaktadır. Ekonomik büyümenin kaynağı olarak; işgücü ve sabit sermaye stokunu alan bu modelde, ekonomik büyümenin artırılabilmesi için nüfusun ya da yatırımların artması gerekmektedir. Yatırımların artırılabilmesi için ise tasarrufların artırılması gerektiğine vurgu yapılmaktadır. Model, genel olarak emek ve sermayenin azalan verimler yasasını temel alır ve ekonomik büyümenin bir noktadan sonra duracağını ifade eder. Bu yönüyle Solow-Swan (1956) modeli bir sınırlı büyüme modelidir (Akkaya, 2016, s. 45). Bu modele Neo-Klasik denilmesinin nedeni; Klasik İktisatçılar gibi tam rekabet koşullarını, üretim faktörlerine marjinal verimliliklerine göre ödeme yapıldığını, tam istihdamı ve değişen bir sermaye-hâsıla oranını kabul ediyor olmalanıdır. Neo-Klasik Ekonomik Büyüme Modelinin temel varsayımları: (i) Ekonomi daima potansiyel çıktı ve tam istihdam düzeyinde dengededir. (ii) Ekonomide homojen tek ürün üretilip, tüketilmektedir. Bu mal aynı zamanda o ülkenin GSYH'sini de oluşturmaktadır. (iii) Tasarruf ve yatırımlar eşittir, bu yüzden modele ayrı bir yatırım fonksiyonun konulmasina gerek yoktur. Neo-Klasik Büyüme Modeli, bir Cobb-Douglass üretim fonksiyonunu temel almaktadır:

$Y=A K^{\alpha} L^{\beta}$

Burada; $Y$; reel milli geliri, $A$; büyümeyi etkileyen teknoloji dâhil tüm dışsal faktörleri, $K$; sermaye stokunu, $L$; işgücü miktarını, $\alpha$; üretimin, sermaye stokuna olan duyarlllı̆̆ını ve $\beta$; üretimin, işgücüne olan duyarllığını ifade etmektedir. Solow-Swan (1956), geliştirdikleri modelde ölçeğe göre sabit getiri varsayımının geçerli olduğunu kabul etmişlerdir.

$\alpha+\beta=1$

$\beta=1-\alpha$

$Y=A K^{\alpha} L^{1-\alpha}$

haline gelir. Solow-Swan (1956) Denklem (12)'yi basitleştirebilmek için, bu eşitliğin her iki yanını işgücüne $(L)$ bölerek, üretim fonksiyonunu, işgücü başına düşen çıktı miktarını $(y)$ gösterecek şekle getirmişlerdir.

$$
\begin{aligned}
\frac{Y}{L} & =\frac{A K^{\alpha} L^{1-\alpha}}{L} \\
y & =A\left(\frac{K}{L}\right)^{\alpha} \\
y & =A k^{\alpha}
\end{aligned}
$$

Denklem (15)'te $y$; işgücü başına düşen üretim miktarını, $k$; işgücü başına düşen sabit sermaye stokunu göstermektedir. Bu durumda üretim, $k$ ’nın bir fonksiyonu haline gelmektedir:

$y=f(k)$

Denklem (16)'da işgücü başına düşen sabit sermaye stoku $(k)$ arttıkça, ekonomik büyümenin de artacağ1 kabul edilmektedir.

Romer (1986) ve Lucas (1988) çalışmalarıyla başlayan İçsel Büyüme Modellerinde; teknoloji, beşeri sermaye yoluyla üretim fonksiyonuna dahil edilmiş ve beşeri sermaye geliştikçe, ekonomik büyümenin de sonsuza kadar devam edeceği belirtilmiştir (Güvel, 2011, s. 106). Teknolojik ilerleme, modelde bir açıklayıcı değişken olarak yer aldığı için bu modellere İçsel Büyüme Modelleri adı verilmiştir. Teknolojik gelişmeyi Romer (1986) Ar\&Ge faaliyetleri yoluyla, Lucas (1988) beşeri sermaye (işgücünün eğitim, sağllk ve deneyim düzeyi) yoluyla ekonomik büyüme modeline dâhil etmişlerdir. Romer (1986), Ar\&Ge faaliyetlerinin, teknolojik ilerleme üzerinden ekonomik büyümeyi etkileyecek çok önemli ve büyüme modellerinden dişlanamayacak kadar yaşamsal bir faktör olduğu ifade etmiştir (Taban, 2010, s. 110-111). Jones (2001), Romer’in ortaya koyduğu bu teoriye Yaratıc1 Fikirler İktisadı adını vermektedir. Romer (1986)'ya göre yaratıcı fikirlerin en önemli özelliği; yüksek fayda sağlayacak çıktı üreterek, teknolojik yeniliklerin kaynağını oluşturması ve Solow-Swan (1956) modelinde yer alan teknoloji değişkeninde artışa yol açmasıdır (Tiryakioğlu, 2006, s. 76-77). Romer (1986), Ar\&Ge faaliyetleri ile üretilen yeni bilgi ve teknolojilerin işgücünün verimliliğini artıracağını ifade ederek, Ar\&Ge faaliyetlerini, işgücünün verimliliği üzerinden büyüme modeline dâhil etmiştir.

$Y=K^{\alpha}(A L)^{1-\alpha}$ 
Denklem (17)'de beşeri sermaye arttıkça, üretim ve ekonomik büyüme de artacaktır. Ar\&Ge faaliyetleri ve teknolojik gelişme, ancak yatırımlarla ve bilinçli çabalarla sağlanabilir. Ar\&Ge faaliyetleri sonucunda geliştirilen yeniliklerin üretim sürecine aktarılması ile ekonomide üretim ve gelir artar, ekonomik büyüme sonsuza kadar devam eder (Taban, 2010, s. 124-125). Romer (1990) çalışmasında; modelde çıtıyı $(Y)$, fiziksel işgücünün $(L)$, nihai çıktı için ayrılan beşeri sermayenin $\left(H_{A}\right)$ ve rekabetçi girdilerin $(x)$ bir fonksiyonu olarak ifade etmiştir:

$$
Y\left(H_{A}, L, x\right)=H_{\gamma}^{\alpha} L^{\beta} \int_{0}^{\infty} x(i)^{1-\alpha-\beta}
$$

Denklem (18)'de teknoloji düzeyi $(A)$ sabit kabul edildiğinde, sabit sermaye stoku şöyle ifade edilebilir:

$K=\eta A \bar{x}$

Buradan üretim fonksiyonu;

$$
\begin{aligned}
& Y\left(H_{A}, L, x\right)=H_{\gamma}^{\alpha} L^{\beta} A \bar{x}^{1-\alpha-\beta} \\
& Y\left(H_{A}, L, x\right)=H_{\gamma}^{\alpha} L^{\beta} A\left(\frac{K}{\eta A}\right)^{1-\alpha-\beta} \\
& Y\left(H_{A}, L, x\right)=\left(H_{\gamma} A\right)^{\alpha}(L A)^{\beta}(K)^{1-\alpha-\beta} \eta^{\alpha+\beta-1}
\end{aligned}
$$

Romer (1986, 1990) çalışmalarıyla ekonomik büyüme teorisine çok önemli katkılarda bulunmuş ve dişsal bir faktör olarak kabul edilen teknolojik ilerlemeyi içselleştirerek, bu sayede ekonomik büyümenin sonsuza kadar devam edebileceğini ortaya koymuştur. Lucas (1988) ise beşeri sermayeyi; bireylerin beceri düzeyinin bir göstergesi olarak kabul etmiş ve bireylerin zamana bağlı değişen üretkenliğini $h(t)$ ile göstermiştir. Lucas (1988) beşeri sermayeye dayalı olarak ortaya koyduğu modelde çıktı; sabit sermeye stoku $(K)$ ve etkin emek $\left(N^{e}\right)$ tarafından belirlenmektedir. $N$ sayıdaki işgücü, sıfır (0) ile sonsuz ( $\left.\infty\right)$ arasında değişen çeşitli yetenek düzeylerine sahiptir:

$N=\int_{0}^{\infty} N(h) d h$

Lucas (1988) modelinde $h$ yetenek düzeyindeki bir işgücü, çalışma zamanını iki şekilde değerlendirmektedir: Birincisi; cari üretim $(u(h))$, ikincisi; beşeri sermaye birikimini $(1-u(h))$ artırmak. Buradan etkin işgücü toplamı:

$N^{e}=\int_{0}^{\infty} u(h) N(h) h d h$

denklemi yardımıla bulunabilir. Bunun sonucunda üretim fonksiyonu; sabit sermaye stoku ile etkin işgücünün bir fonksiyonu olarak ifade edilmektedir:

$Y=F\left(K, N^{e}\right)$

Lucas (1988), beşeri sermayenin içsel ve dişsal olmak üzere iki tür etki ortaya koyduğunu ifade etmiş ve beşeri sermayenin dişşal etkisini hesaba katarak, beşeri sermayeyi aşağıdaki şekilde hesaplamıştır:

$h_{a}=\frac{\int_{0}^{\infty} h N(h) d h}{\int_{0}^{\infty} N(h) d h}$

Lucas (1988), beşeri sermayenin sürekli artırılmasının, ekonomik büyümeyi de sürekli olarak artırabileceğini ifade etmiştir (Tiryakioğlu, 2006, s. 75-76).

\section{Finansal Gelişme ve Ekonomik Büyüme İlişkisi}

Neo-Klasik İktisatçılar; Klasik iktisatçıların üretim ve dış ticarette uygulanmasını önerdikleri liberal ekonomi politikalarının, finans sisteminde de uygulanabilmesinin gerektiğini ve bunun ekonomik büyümeyi olumlu yönde etkileyeceğini iddia etmişlerdir. Sanayi devrimi ile birlikte artan gelir ve tasarrufların verimli şekilde yönetilmesi ve bu kaynakların, doğru bir şekilde reel sektör yatırımlarına dönüştürülmesi, 19. yy ortalarında önemli bir konu haline gelmiştir. 19. yy sonlarına gelindiğinde ekonomide; finansal sektör ve reel sektör olmak üzere, birbiriyle bütünleşik ikili bir yapı meydana gelmiştir. Bu iki sektör arasındaki karşılıklı etkileşim, Neo-Klasik iktisatçılar tarafından yoğun bir şekilde incelenmeye 
ve tartışılmaya başlanmıştır (Durusu Çiftçi, 2015, s. 9-10). Keynesyen iktisatç1lar ise; finans sektörünün, ekonomik büyümede istikrarsızlıklara neden olabileceğini, bu nedenle devlet müdahalesi altında olmas1 gerektiği ifade etmişlerdir (Erdem ve Dumrul, 2014, s. 45). Harrod $(1937,1939)$ ve Domar $(1946,1947)$ çalışmalarıyla geliştirilen Post Keynesyen Büyüme Modelinde; Keynesyen İktisat Teorisinde eksik kalan makroekonomik analizlerin mikroekonomik temelleri oluşturulmaya çalışılmış, ekonomik karar birimlerinin fayda ve beklentileri de analizlere dâhil edilmiştir. Bu akıma Neo-Klasik İktisatçılar da destek vermiştir. Neo-Klasik iktisatçılar, piyasaların etkin çalışabilmesi için finansal işlemlerde de reel sektöre ait işlemlerde de tam serbestleşmenin gerektiğini dile getirmişlerdir (Emek, 2000, s. 68). Finansal piyasalarda tam serbestinin sağlanabilmesi için ise Keynesyen İktisatçıların öne sürdüğü devlet kontrollerinin gevşetilmesinin (deregülasyon) gerektiğini savunan Neo-Klasik iktisatçlar, finans piyasalarında uluslararası serbestleşmenin ve küreselleşmenin, tüm ülkelerin finansal derinliğini ve çeşitliliğini artırarak, ekonomik büyümelerini hızlandırabilmeleri için en iyi yol olduğunu iddia etmişlerdir (Atamtürk, 2007, s. 76-77). Solow-Swan (1956) tarafindan geliştirilen Neo-Klasik Dışsal Büyüme Modelinde de tasarruflar, ekonomik büyümenin dinamiğini oluşturmakta olup, tasarrufların ve yatırımların artırılabilmesi için gelişmiş finansal piyasalara gereksinim duyulduğu ifade edilmiştir (Yülek, 1997, s. 94-95).

Neo-Klasik Büyüme Modelinde dişsal olarak kabul edilen teknoloji, İçsel Büyüme Modellerinde ekonomik büyümenin önemli bir dinamiği olarak yer almıştır. Ar\&Ge faaliyetleri, inovasyon, bilgi, teknolojik ilerleme, beşeri sermaye, işbölümü ve uzmanlaşma, ölçek ekonomileri, dışsallıklar ve yayılma etkileri, altyap1 yatırımları, kamu harcamaları ve politikaları, ülkelerin sahip oldukları kurumsal yap1 ve kurumsal kalite, İçsel Büyüme Modellerinde ekonomik büyümenin önemli dinamikleri olarak yer almıştır. Bu yaklaşımda; ekonomik büyüme modelinde yer verilen değişkenlerin büyük bir kısmı, finansal sisteminin gelişmişlik düzeyiyle yakından ilişkilidir. İçsel Büyüme Modelini savunan iktisatçılara göre; finansal sistem, reel sektörün teknoloji ve yenilik geliştirmesini kolaylaştırarak, ekonomik büyümeyi hızlandıracaktır (Demir ve Üzümcü, 2003, s. 17). İçsel Büyüme Teorisini savunan iktisatçlara göre; az gelişmiş veya gelişmekte olan ülkeler, finansal sistemlerini geliştirmeye ve serbestleştirmeye yönelik gerekli adımları atmazlar ve ihtiyaç hissedilen reformları yapmazlarsa, gelişmiş ülkelerle aralarındaki kalkınma farkını kapatamazlar. Bu da Solow (1956)'nın öne sürdüğü yakınsama hipotezinin hiçbir zaman gerçekleşmeyeceği anlamına gelmektedir (Erdem ve Dumrul, 2014, s. 66-67).

Finansal gelişme ve ekonomik büyüme ilişkisinin yönünün belirlenmesi üzerine yapılan çalışmalarla üç farklı hipotez geliştirilmiştir: Birincisi; finansal gelişmenin, reel sektöre ihtiyaç duyduğu fonları arz ederek, ekonomik büyümeyi desteklediği Arž-Öncüllï Finansal Gelişme Hipotęi, ikincisi; ekonomik büyümenin artmasıyla birlikte, ekonomide gelir, tasarruf ve finansal işlemlere olan talebin artarak, finansal sistemin gelişimi hızlanacağına yönelik Talep-Takipli Finansal Gelişsme Hipotę̧i ve üçüncüsü; ekonomik büyüme ile finansal gelişme arasında karşıllklı etkileşimin bulunduğuna dair Karşıllkel Nedensellik. Hipoteridir. Ayrıca bu değişkenler arasında negatif ilişkinin ${ }^{5}$ olduğunu veya herhangi bir etkileşimin olmadığını öne süren hipotezlere de rastlanmaktadır.

\section{Enerji Tüketimi ve Ekonomik Büyüme İlişkisi}

Enerji tüketimi ile ekonomik büyüme arasındaki ilişkiler, teorik ve uygulamalı ekonomi literatürünün başlıca araştırma konularından biridir. Sürdürülebilir ve yüksek bir ekonomik büyüme için enerji kullanımı ve enerji arz güvenliği büyük önem taşımaktadır. Enerji, üretimin ve ekonomik büyümenin lokomotifi olarak kabul edilmektedir (Aydın, 2010, s. 318). 18. yy'ın sonlarında buharlı makinelerin bulunması ve 19. yy'ın başlarından itibaren bunun sanayi sektöründe kullanılmaya başlanmasıyla birlikte, seri ve büyük ölçekli üretime geçilmiştir. Literatüre Sanayi Devrimi olarak giren bu süreçte ülkelerin enerji gereksinimi hızla artmış, enerji kaynaklarına sahip olabilmek için birçok savaş ve barışlar yapılmıştır (Arslan ve Demirağ, 2017, s. 5-6). 21. yy’a gelindiğinde enerji, modern yaşamın en temel vazgeçilmezleri arasina

\footnotetext{
5 Mattesini (1996), gelişmiş finansal sistemlerde, kredi piyasalarında asimetrik bilgiden kaynaklanan risklerin azaltılabilmesi için finans kurumlarının önemli ölçüde inceleme ve izleme maliyetlerine katlanmak zorunda kaldıklarını, bunun ekonomideki kaynak dağıtım etkinliğini bozarak, ekonomik büyümeye zarar verebildiğini ifade etmiştir. Yazar bu görüşüne; gelişmiş finansal piyasalarda artan finansal araç çeşitliliğini, bu araçların taşıdığı risklerin ancak konunun uzmanları tarafindan belirlenebilmesinin mümkün olduğunu ve bu tür uzmanlık faaliyetlerinin de finansal aracllı sistemleri üzerinden ekonomilere ek bir yük getirmesini gerekçe göstermiştir. Yeldan (2009), kendisinin Türkçe iktisat literatürüne kazandırdığı Sermayenin Finansallaşması kavramı kapsamında; gelişen finansal piyasaların ve artan finansal aktivitelerin, reel üretimde kullanılması gereken bir kısım fonların, özellikle faizlerin yüksek olduğu dönemlerde, reel yatırımlara oranla daha risksiz ve yüksek getiri sağlayan finansal piyasalarda değerlendirilmesine neden olarak, ekonomideki yatırım ve üretimi azaltacağını ve bu yönüyle ekonomik büyümeye zarar vereceğini ifade etmektedir.
} 
girmiş olup, günümüzde üretimden taşımaya, depolamadan pazarlamaya, servis hizmetlerinden tüketime kadar her alanda enerji, yaşamın temel girdisi haline gelmiştir.

Literatürde enerji tüketimi ile ekonomik büyüme arasındaki ilişkiler, enerji tüketiminin ekonomik büyümeye etkileri ve ekonomik büyümenin enerji tüketimine etkileri şeklinde iki yönden analiz edilebilmektedir. Genel kabul; artan enerji kullanımının, üretimi ve ekonomik büyümeyi de artıracağı, öte yandan artan ekonomik büyümenin de enerji tüketimine dayalı teknolojik ilerlemeler ve üretim sürecindeki kullanım gereği, enerji tüketimini artıracağı yönündedir. Özellikle 2005 yllında imzalanan Kyoto Protokolü çerçevesinde ülkeler; çevreye duyarlı ve atmosferi daha az kirletecek üretim teknolojileri kullanmaya ve bir yandan ekonomik büyümelerini artırırken, diğer yandan enerji verimliliği ve enerji tasarrufunu da göz önünde bulundurmaya başlamışlardır.

Son yüz yılda ekonomistler; ekonomik büyüme ile çevre kirliliği arasındaki ilişkiyi yoğun biçimde analiz etmeye başlamışlardır. Kuznets (1955) yaptığ çalış̧mada; gelir dağılımı ile ekonomik büyüme arasındaki ilişkiyi incelemiş ve bu değişkenler arasında ters $U$ şeklinde bir ilişkinin var olduğunu ortaya koymuştur. Literatüre Kuznets Eğrisi olarak giren bu yaklaşım, küresel ısınma ve hava kirliliğinin arttığ1 1990'lı yıllarda çevre kirliliği ve ekonomik büyüme (milli gelir) arasındaki ilişkiye uyarlanmış ve böylece Çevresel Kuznets Eğrisi (ÇKE) literatüre girmiştir (Koçak, 2014, s. 62). ÇKE Hipotezine göre ülkeler, kişi başına düşen milli gelirleri belirli bir seviyeye gelinceye kadar çevre kirlenmesini göz ardı etmekte, ancak zamanla artan sağlık sorunları ve temiz su ve havanın yetersiz gelmeye başlaması nedeniyle, çevreyi koruyucu önlemler almaya başlamaktadırlar. Literatürde karbon dioksit emisyonu (çevre kirliliği) ile milli gelir arasındaki ilişkinin klasik (ters $\mathrm{U}$ şeklindeki) ÇKE şeklinde olmayabileceğini iddia eden yeni yaklaşımlar da bulunmaktadır.

Sinha ve Bhatt (2017) ve Özkoç, Yıldırım ve Kudubeş (2017) çevre kirliliği ile milli gelir arasındaki ilişskinin U şeklinde olacağını ifade etmektedirler. Bu araştırmacılara göre; yapılan ekonometrik analizler, tarihin ilk yıllarından başlamadığı için, zaten ülkeler doğayı belirli bir ölçüde kirletmiş durumdalar (Yani U'nun ilk çizgisinin üstündeler). Ülkeler, artan çevre bilinci, uluslararası yaptırımlar ve gelişen teknolojiye bağlı olarak, çevreyi daha az kirletmeye başlamışlardır. Ancak, bu işlemin kendine göre ek maliyetleri ve üretime getirdiği kıstllamalar nedeniyle ekonomide kâr düşüşleri söz konusudur. Uzun dönemde daha fazla büyümek isteyen ekonomiler, belirli bir noktadan sonra çevre politikalarını göz ardı etmeye ve üretimi, kârllığgı ve ekonomik büyümelerini artırmayı öncelemeye başlayacaklar. Bu da çevre kirliliğinin tekrar artmasına neden olacaktır. Şahinöz ve Fotourehchi (2013) ve Allard vd. (2018) ise çevre kirliliğgi ile milli gelir arasındaki ilişkinin $\mathrm{N}$ şeklinde olacağını ifade etmekte, yaptıkları analizlerle de bu görüşlerini desteklemektedirler. Bu yazarlar da konuya $\mathrm{U}$ şeklini savunan araştırmacılar gibi yaklaşmakta, sadece tarihsel perspektifi biraz daha geniş tutmaktadırlar. $\mathrm{Bu}$ araştırmacılara göre; ülkeler ekonomik büyümelerinin ilk yıllarında kullandıkları düşük teknolojili ürünler, fabrikalar ve arabalar nedeniyle çevreyi çok kirleteceklerdir. Kişi başına düşen milli gelirin artmasıyla birlikte, çevre sorunlarına olan duyarlılık artacak, çevre kirliliği azaltılmaya çalışlacaktır. Ancak belirli bir gelir seviyesinin üstüne çıkabilmek için tekrar çevreyi koruma politikalarını göz ardı edecekler ve çevre kirliliği tekrar artmaya başlayacaktır. Mert ve Bozdağ (2013); Dam, Karakaya ve Bulut (2013); Aytun (2014); Engin Balın ve Mumcu Akan (2015) ise çevre kirliliği ile milli gelir arasındaki ilişkinin ters $\mathrm{N}$ şeklinde çıkabileceğini öne sürmektedir.

\section{Türkiye Ekonomisinde Finansal Gelişme, Enerji Tüketimi ve Ekonomik Büyüme Etkileşimi}

Finansal gelişme genel olarak; bankacılık sektörü ve menkul kıymetler borsası üzerinden tanımlandığı için, çalışmanın bu aşamasında da Türkiye'de finansal gelişme ile ekonomik büyüme arasındaki ilişkiler, bu değişkenler üzerinden incelenmiştir. Bu amaçla; Türk bankacılık sistemindeki mevduat miktarı, kredi miktarı ve milli gelir arasındaki ilişkiler, Şekil 1 yardımıyla incelenmiştir. 


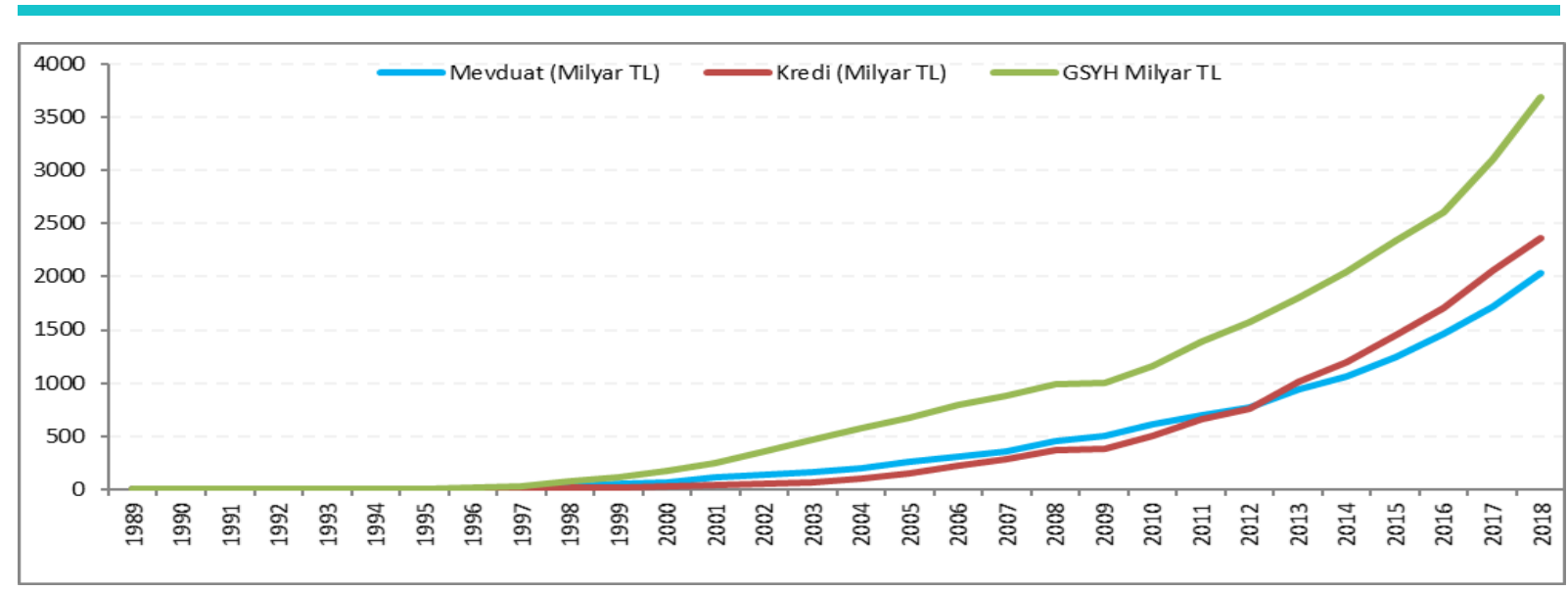

Şekil 1. Türk Bankaullk Sistemindeki Mevduat Miktar, Kredi Miktar ve Milli Gelir Arasındaki İlişkiler

Kaynak: World Bank (2019a), TBB (2019a, 2019b), EVDS (2019a)'dan alınan veriler kullanılarak yazar tarafindan hazırlanmiştır.

Şekil 1'den de görüldüğü üzere; Türkiye'de bankacılık sektöründeki asıl gelişmeler, 1997 y1lindan sonra başlamıştır. Bu dönemde bankacılık sektöründe yer alan mevduatlar, bankacılık sektörü tarafindan ekonomiye verilen krediler ve milli gelir arasında oldukça güçlü ve yakın ilişkiler olduğu görülmektedir. 2012 yılına kadar mevduatlardan az olan kredilerin, bu tarihten itibaren mevduatları aştığı görülmektedir. $\mathrm{Bu}$ durumda yurtiçi yerleşiklerin kredi talebi, yurtdışı tasarruflar (sendikasyon kredileri) kullanılarak karşılanmakta, bu da ülkenin dış borç stokunu artırmaktadır. Aynı dönemde Borsa İstanbul'un işlem hacmi ile GSYH arasındaki ilişkiler Şekil 2'de yer almaktadır.

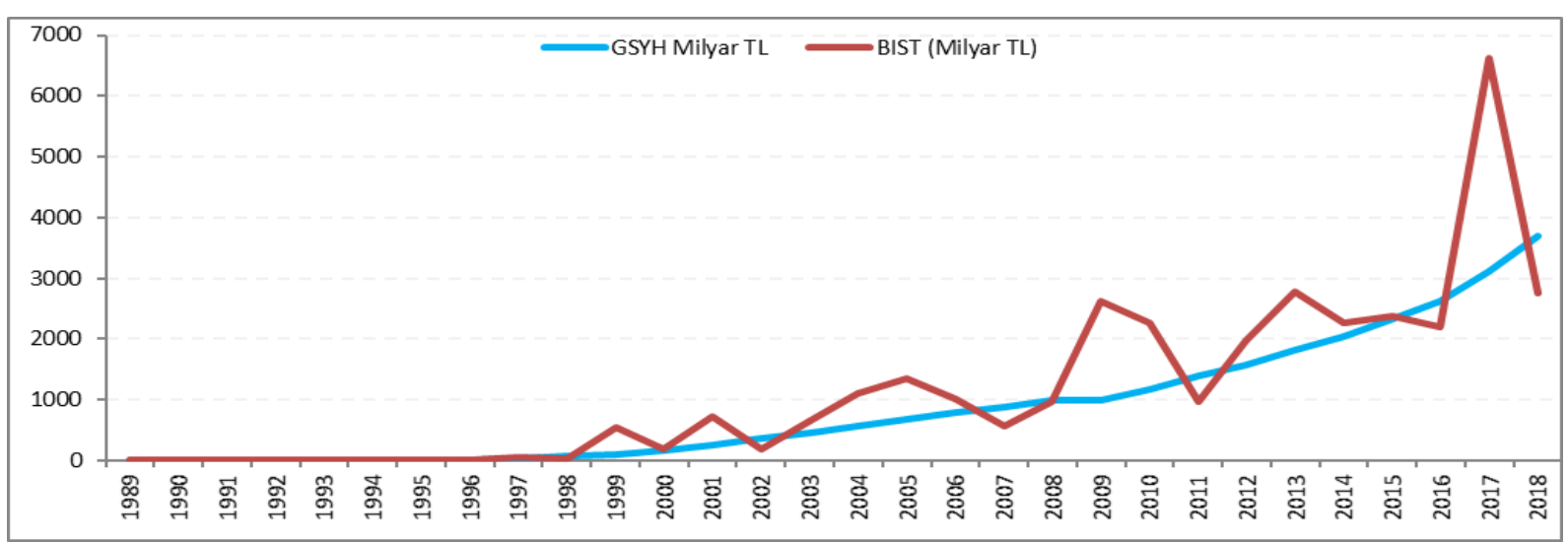

Şekil 2. Borsa İstanbul'un İslem Hacmi İle GSYH Arasındaki İlişkiler

Kaynak: World Bank (2019a), TBB (2019a, 2019b), EVDS (2019b)'den alınan veriler kullanılarak yazar tarafindan hazırlanmıştır.

Şekil 2'den de görüldüğü üzere; borsa endeksi milli gelirden daha hızlı artmakta ve daha fazla oynaklık göstermektedir. Elbette ki borsadaki artışlar, reel sektörün yatırım olanaklarını artırarak, ekonomik büyümeyi desteklemektedir. Ancak borsadaki oynaklı̆̆ın azaltılmasında yarar vardır. Aksi takdirde ekonomiye fayda değil, zarar verebilecektir. Şekil 1 ve Şekil 2 birlikte değerlendirildiğinde; Türkiye'de finansal gelişme ile ekonomik büyüme arasında eşanlı bir hareketin olduğu söylenebilir. Türkiye ekonomisinde enerji tüketimi (petrol eşdeğeri, Milyon $\mathrm{Kg}$ ) ile gayri safi yurtiçi hâsıla (GSYH, Milyar \$) arasındaki ilişkiler Şekil 3 yardımıyla incelenebilir. 


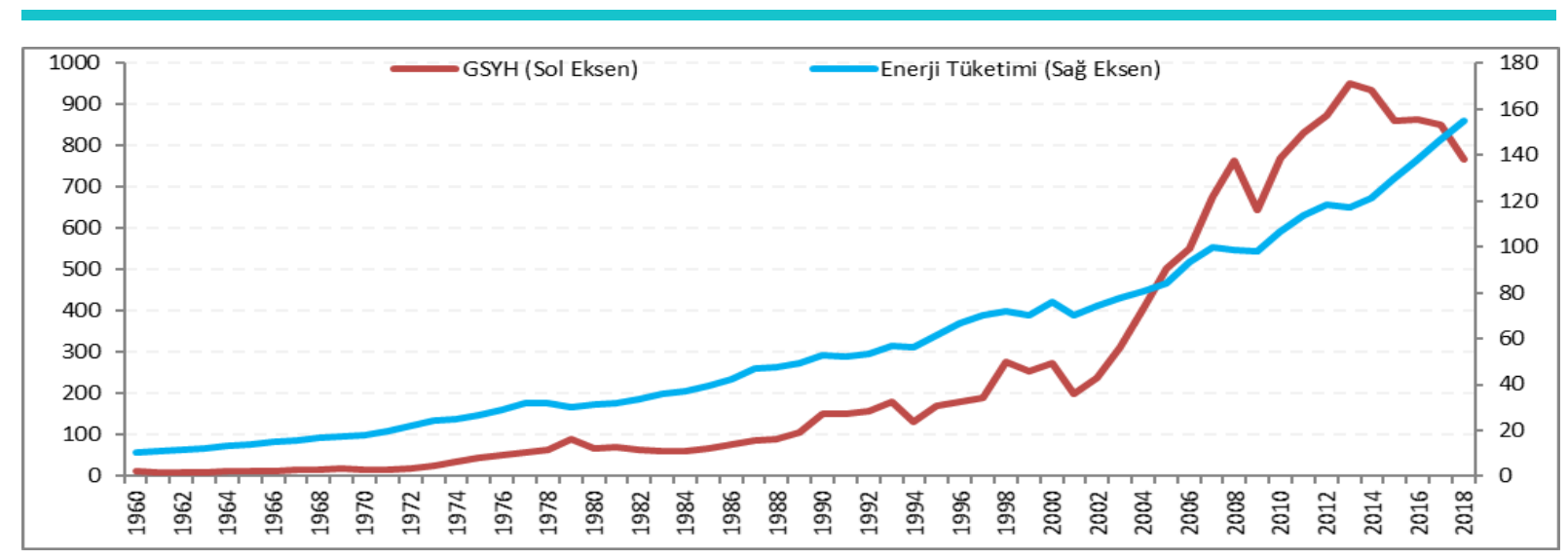

Şekil 3. Elek.trik Tüketimi İle Milli Gelir Arasindaki Ilişki

Kaynak: World Bank (2019a, 2019b, 2019c)'den alınan veriler kullanılarak yazar tarafından çizilmiştir.

Şekil 3’ten da görüldüğü üzere; Türkiye'de enerji tüketimi ile milli gelir artışı arasında yakın bir etkileşim bulunmaktadır. Şekil 3’teki artışlar üzerinde nüfus artışının da etkili olabileceği unutulmamalıdır. Hatta GSYH üzerinde fiyat artışlarının (enflasyonun) da etkileri olacaktır. Bu değişkenler arasındaki ilişkiyi daha net ortaya koyabilmek için; kişi başına düşen enerji tüketimi (petrol eşdeğeri, Kg) ile kişi başına düşen reel GSYH (2010 yılı fiyatlarıyla hesaplanmış, \$) arasındaki ilişkilere de bakmakta yarar vardır. Bu değişkenler arasındaki ilişkiler Şekil 4'te yer almaktadır.

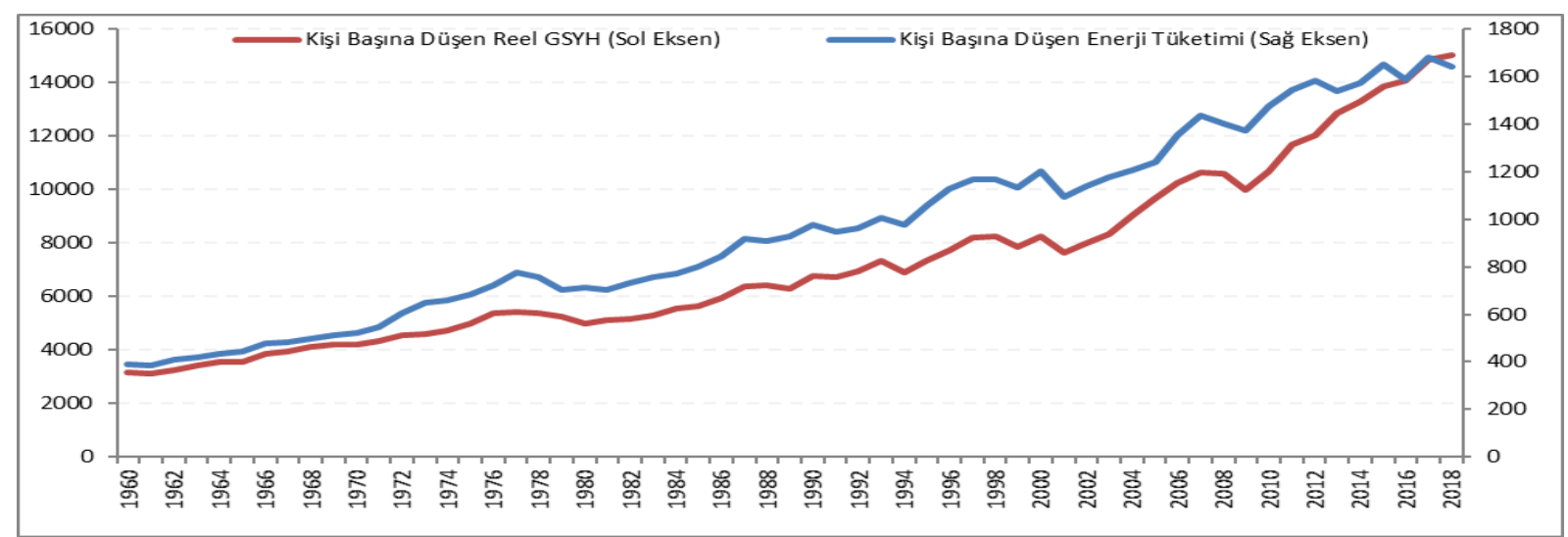

Şekil 4: Kiş̧i Başına Düsen Elektrik Tüketimi ile Kiş̧i Başına Düssen Reel Milli Gelir Arasındaki İlişkiler

Kaynak: World Bank (2019b, 2019e)'den alınan veriler kullanılarak yazar tarafından çizilmiştir.

Şekil 4’te kişi başına düşen elektrik tüketimi ile kişi başına düşen reel milli gelir arasındaki ilişki incelendiğinde; veriler nüfus artışı etkilerinden ve fiyat etkilerinden arındırıldığı halde de Türkiye'de enerji tüketimi ile ekonomik büyüme arasında yakın bir etkileşimin olduğu görülmektedir. Hatta serilerin bu formunda, enerji tüketimi ile milli gelir artışı arasındaki ilişkiler daha güçlü ve net biçimde görülebilmektedir.

\section{Literatür İncelemesi}

Çalışmanın bu bölümde; finansal gelişme, enerji tüketimi ve ekonomik büyüme arasındaki ilişkileri inceleyen yabancı ve yerli çalışmaların özetlerine yer verilmiştir. Bu işlemi yaparken; önce gelişmiş ülkeler, sonra gelişmekte olan ülkeler ve son olarak da az gelişmiş ülkeler için yapılmış çalışmaların özetine yer verilmiştir. Ülkelerin sınıflandırılmasında Birleşmiş Milletlerce hazırlanan UN (2020) çalışması temel alınmıştır. Her bir çalışma grubu kendi içinde, çalışmanın yayınlanma tarihi sırasına göre düzenlenmiştir.

\section{Gelişmiş Ülkeler İçin Yapılmış Çalışmaların Özeti}

Şentürk (2012), enerji tüketiminin ekonomik büyüme üzerindeki etkilerini, ABD, İngiltere, Fransa, Kanada ve Japonya için enerji kaynakları açısından analiz etmiştir. Granger nedensellik testi sonucunda; enerji tüketimi ile ekonomik büyüme arasında ABD ve Kanada'da iki yönlü nedensellik ilişkileri belirlenirken, Fransa ve Japonya'da bu değişkenler arasında herhangi bir nedensellik ilişkisinin olmadığ tespit edilmiştir. VEC analizinde; enerji tüketimindeki \%1'lik artışın milli geliri ABD’de \%0,23, Kanada'da 
\%0,43 ve Fransa'da \%0,46 artırdığı belirlenmiştir. Kasperowicz (2014), elektrik tüketimi ile ekonomik büyüme arasındaki ilişkileri, Polonya'nın 2000-2012 dönemi verilerini kullanarak analiz etmiş ve Polonya'da elektrik tüketimi ile ekonomik büyüme arasında iki yönlü nedensellik ilişkilerinin olduğu tespit edilmiştir. Ayrıca; sabit sermaye oluşumu ile ekonomik büyüme arasında da karşılıklı nedensellik ilişskilerinin olduğu bulgusuna ulaşılmıştır. Magazzino (2016), enerji tüketimi, reel GSYH ve finansal gelişme arasındaki ilişkileri, İtalya'nın 1960-2014 dönemi verilerini kullanarak ARDL yöntemiyle araştırmıştır. Seriler arasındaki uzun ve kısa dönem ilişkileri ARDL yöntemiyle analiz edilmiş, reel GDP'deki artışların enerji tüketimini artırdığ1, petrol fiyatlarındaki artışların ise enerji tüketimini azalttı̆̆1 tespit edilmiştir. Seriler arasındaki nedensellik ilişkileri Toda-Yamamoto yöntemiyle incelenmiş ve reel GSYH'den enerji tüketimine doğru tek yönlü nedensellik ilişkisi belirlenmiştir. Gomez ve Rodriguez (2019), enerji tüketimi ile finansal gelişme arasındaki ilişkileri, NAFTA ülkelerinin 1971-2015 dönemi verilerini kullanarak, panel veri analizi yöntemiyle incelemiştir. Uzun dönem katsayıları Panel DOLS ve Panel FMOLS yöntemleriyle tahmin edilmiş ve finansal gelişme, enflasyon, kentleşme ve ticari dişa açıklıktaki artışların enerji tüketimini azalttığı, milli gelirdeki artışların ise enerji tüketimini artırdığ1 görülmüştür. Yağlı ve Topçu (2019), G7 ülkelerindeki finansal gelişme ile ekonomik büyüme arasındaki ilişkileri, 2005-2015 dönemi verilerini kullanarak Panel VECM yöntemi ile analiz etmiştir. Çalışmada; Temel Bileşenler Analizi kullanılarak, üç farklı finansal gelişmişlik endeksi hesaplanmıştır. Uzun dönemde; her üç finansal gelişme göstergesinden de ekonomik büyümeye doğru tek yönlü nedensellik ilişkisinin var olduğu görülmüştür. Kısa dönem analizindeyse; finansal etkinlik ile ekonomik büyüme arasında karşllklı nedensellik ilişkisi tespit edilmiştir. Anton ve Nucu (2020), finansal gelişmenin yenilenebilir enerji tüketimi üzerindeki etkilerini, 28 Avrupa Birliği ülkenin 1990-2015 dönemi verilerini kullanarak, panel veri analizi yöntemiyle incelemiştir. Sabit etkili panel regresyon analizinde; finansal gelişmenin, yenilenebilir enerji tüketimini pozitif etkilediği belirlenmiştir. Gelişmiş ülkeler için yapılmış finansal gelişme, enerji tüketimi ve ekonomik büyüme konulu çalışmaların kısa özeti Tablo 1'de yer almaktadır.

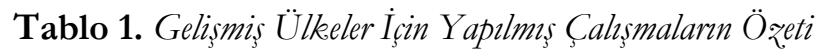

\begin{tabular}{|c|c|c|c|c|}
\hline $\begin{array}{l}\text { Yazar(lar) ve } \\
\text { Yayin Yil1 }\end{array}$ & Ülke & Dönem & Yöntem & Bulgular \\
\hline Şentürk (2012) & $\begin{array}{l}\text { ABD, } \\
\text { İngiltere, } \\
\text { Fransa, } \\
\text { Kanada ve } \\
\text { Japonya }\end{array}$ & $1973-2010$ & $\begin{array}{l}\text { VAR Analizi, VEC } \\
\text { Analizi, Granger } \\
\text { Nedensellik Testi }\end{array}$ & $\begin{array}{l}\text { Enerji tüketimiyle ekonomik büyüme arasında ABD ve Kanada'da iki } \\
\text { yönlü nedensellik ilişkisi belirlenirken, Fransa ve Japonya'da bir } \\
\text { nedensellik ilişkisi görülmemiştir. Enerji tüketimindeki \%1'lik artışın } \\
\text { milli geliri ABD'de \%0,23, Kanada'da \%0,43 ve Fransa'da \%0,46 } \\
\text { artırdığ1 belirlenmiştir. }\end{array}$ \\
\hline $\begin{array}{l}\text { Kasperowicz } \\
\text { (2014) }\end{array}$ & Polonya & $2000-2012$ & $\begin{array}{l}\text { Granger Nedensellik } \\
\text { Testi }\end{array}$ & $\begin{array}{l}\text { Polonya'da elektrik tüketimi ile ekonomik büyüme arasında karşllıklı } \\
\text { nedensellik ilişkisi bulunmuştur. Ayrıca; sermaye ile ekonomik büyüme } \\
\text { arasında karşlıklı nedensellik ilişskisi bulunmuştur. }\end{array}$ \\
\hline Magazzino (2016) & İtalya & $1960-2014$ & $\begin{array}{l}\text { ARDL, Toda- } \\
\text { Yamamoto } \\
\text { Nedensellik Testi }\end{array}$ & $\begin{array}{l}\text { Reel GSYH'deki artışların enerji tüketimini artırdığı, petrol fiyatlarındaki } \\
\text { artışlarınsa enerji tüketimini azalttığı belirlenmiştir. Reel GSYH'den } \\
\text { enerji tüketimine doğru tek yönlü nedensellik ilişkisi belirlenmiştir. }\end{array}$ \\
\hline $\begin{array}{l}\text { Gomez ve } \\
\text { Rodriguez (2019) }\end{array}$ & $\begin{array}{l}\text { NAFTA } \\
\text { ülkeleri }\end{array}$ & $1971-2015$ & $\begin{array}{l}\text { Panel DOLS, Panel } \\
\text { FMOLS }\end{array}$ & $\begin{array}{l}\text { Finansal gelişme, enflasyon, kentleşme ve ticari dışa açılıktaki artışların } \\
\text { enerji tüketimini azalttığı, milli gelirdeki artışlarınsa enerji tüketimini } \\
\text { artırdığ1 görülmüş̧ür. }\end{array}$ \\
\hline $\begin{array}{l}\text { Yağlı ve Topçu } \\
\text { (2019) }\end{array}$ & G7 ülkeleri & $2005-2015$ & Panel VECM & $\begin{array}{l}\text { Uzun dönemde; finansal gelişme göstergelerinden ekonomik büyümeye } \\
\text { doğru tek yönlü nedensellik ilişkisi bulunmuştur. Kısa dönemdeyse; } \\
\text { finansal etkinlik ile ekonomik büyüme arasında karşıllklı nedensellik } \\
\text { ilişkisi belirlenmiştir. }\end{array}$ \\
\hline $\begin{array}{l}\text { Anton ve Nucu } \\
(2020)\end{array}$ & 28 AB Ülkesi & $1990-2015$ & Sabit Etkiler Modeli & $\begin{array}{l}\text { Panel regresyon analizinde; finansal gelişmenin, yenilenebilir enerji } \\
\text { tüketimini pozitif etkilediği belirlenmiştir. }\end{array}$ \\
\hline
\end{tabular}

\section{Gelişmekte Olan Ülkeler İçin Yapılmış Çalışmaların Özeti}

Aytaç (2010), Türkiye ekonomisinde enerji tüketimi ile ekonomik büyüme arasındaki ilişkileri, 19752006 dönemi, GSYH, enerji tüketimi, sabit sermaye stoku ve işgücü verilerini kullanarak, Granger nedensellik testi ve VAR analizi ile incelemiştir. Nedensellik analizinde; enerji tüketiminden işgücüne ve ekonomik büyümeden sermayeye doğru tek yönlü nedensellik ilişkileri belirlenmiştir. Varyans ayrıştırması analizinde; ekonomik büyümedeki değişimlerin \%14’ünün enerji tüketimi tarafından açıklanabildiği belirlenmiştir. Özata (2010), enerji tüketimi ile GSYH arasındaki ilişkileri, Türkiye'nin 1970-2008 dönemi verilerini kullanarak analiz etmiş ve milli gelirdeki \%1'lik artışı, enerji tüketimini $\% 0,97$ oranında artırdığını bulmuştur. Enerji tüketimindeki $\% 1$ lik artışı ise milli geliri $\% 0,57$ oranında artırdığ1 görülmüştür. Dumrul (2011), ekonomik büyüme ile enerji tüketimi arasindaki ilişkileri, Türkiye’nin 19602008 dönemi enerji tüketimi ve ekonomik büyüme verileri ve 1950-2007 dönemi CO2 salınımı ve ekonomik büyüme verilerini kullanarak, zaman serisi analizi yöntemleriyle incelemiştir. Analiz sonuçlarına 
göre; Türkiye'de ilgili dönemde enerji tüketimindeki $\% 1$ lik artş̧, ekonomik büyümeyi $\% 0,49$ oranında artırmıştır. Bu analizler Sınır Testi ve ARDL yöntemleriyle yenilendiğinde enerji tüketimindeki \%1'lik artışın, ekonomik büyümeyi \%0,51 oranında artırdığ1 tespit edilmiştir. Bozoklu ve Yılanc1 (2013), gelişmekte olan ülkelerde finansal gelişme ile ekonomik büyüme arasındaki ilişkileri, 1988-2011 dönemi, yurtiçi kredilerin GSYH'ye oranı ve kişi başına reel GSYH büyüme oranı verilerini kullanarak, Dumitrescu ve Hurlin (2012) panel nedensellik testi ile analiz etmişlerdir. Analizler sonucunda; finansal gelişmenin, ekonomik büyümenin belirgin biçimde nedenseli olduğu bulunmuştur. Özcan (2013), Türkiye'de finansal gelişme ile ekonomik büyüme arasındaki ilişkileri, 1987:1-2012:4 dönemi için araştırmıştır. Aralarında eşbütünleşme ilişkisi bulunan seriler arasındaki uzun dönemli nedensellik ilişkileri VECM yöntemiyle, eşbütünleşik olmayan seriler arasındaki kısa dönemli nedensellik ilişkileri de Granger nedensellik testiyle incelenmiş ve finansal gelişme ile ekonomik büyüme arasında uzun dönemli, finansal derinlik göstergeleri ile ekonomik büyüme arasında da kısa dönemli ve karşıllıklı nedensellik ilişkilerinin var olduğu belirlenmiştir. Erdoğan ve Gürbüz (2014), Türkiye'de enerji tüketimi ve ekonomik büyüme arasındaki ilişkileri, 1970-2009 dönemi için, yapısal kırılmalı zaman serisi analizi yöntemleriyle incelemiş ve Reel GSYH'den sermaye stokuna, enerji tüketiminden sermaye stokuna, ihracattan Reel GSYH'ye, ihracattan enerji tüketimine ve ihracattan sermaye stokuna doğru tek yönlü nedensellik ilişkileri tespit ederken, enerji tüketimi ile ekonomik büyüme arasında herhangi bir nedensellik ilişkisi belirleyememiştir.

Hayaloğlu (2015), finansal gelişme ve ekonomik büyüme arasındaki ilişkileri, kırılgan beşli ülkeleri için 1990-2012 dönemi verilerini kullanarak, dinamik panel veri analizi yöntemiyle incelemiştir. Arellona ve Bover (1995) tarafından geliştirilen sistem GMM yöntemiyle gerçekleştirilen çalışmanın sonucunda; bu ülkelerde finansal gelişmişlik düzeyi ile ekonomik büyüme arasında pozitif yönlü bir ilişsinin var olduğu tespit edilmiştir. Contürk ve Güngör (2016), finansal gelişme ile ekonomik büyüme arasındaki ilişkileri, asimetrik nedensellik testiyle incelemiştir. Çalışmada Türkiye'nin 1998-2014 dönemi çeyreklik verileri kullanılmıştır. Granger nedensellik testinde; finansal gelişme ile ekonomik büyüme arasında karşılıkl, asimetrik nedensellik testinde ise ekonomik büyümeden finansal gelişmeye doğru tek yönlü nedensellik ilişkileri tespit edilmiştir. Doğan ve Değer (2016), Hindistan'da enerji tüketimi, finansal gelişme ve ekonomik büyüme arasındaki ilişkileri, 1970-2013 dönemi için analiz etmişlerdir. Çalışmada Granger nedensellik testini kullanan araştırmacılar, ekonomik büyümeden enerji tüketimine doğru bir nedensellik ilişkisi bulurken, enerji tüketiminden ekonomik büyümeye doğru böyle bir ilişki tespit edememişlerdir. Ek olarak ekonomik büyümeden finansal gelişmeye doğru da bir nedensellik ilişkisi olduğu görülmüştür. Johansen testi sonucunda serilerin eşbütünleşik oldukları görülmüş, uzun dönem analizi sonucunda; enerji tüketimindeki \%1'lik artışı ekonomik büyümeyi $\% 0,98$, finansal gelişmedeki $\% 1$ 'lik artışın ise ekonomik büyümeyi \%0,18 oranında artırdığı tespit edilmiştir. Mammadov (2016), Azerbaycan'da finansal gelişme ile ekonomik büyüme arasındaki ilişkileri, 2001:Q1-2014:Q4 dönemi için Toda-Yamamoto nedensellik testiyle incelemiştir. Analizler sonucunda; Azerbaycan ekonomisinde, McKinnon-Shaw tarafindan ileri sürülen Arz Öncüllü Hipotezin geçerli olduğu ve finansal gelişmeden, ekonomik büyümeye doğru bir nedensellik ilişkisinin bulunduğu tespit edilmiştir. Lu (2017), elektrik tüketimi ile ekonomik büyüme arasındaki ilişkiyi, Tayvan'daki 17 sanayi sektörüne ait 1998-2014 dönemi verilerini kullanarak, panel veri analizi yöntemiyle incelemiş ve elektrik tüketimi ile ekonomik büyüme arasında karşllkkl nedensellik ilişkileri tespit etmiştir. Yapılan regresyon analizinde ise elektrik tüketimindeki $\% 1$ lik artışın, ekonomik büyümeyi $\% 1,72$ oranında artırdığ1 görülmüştür. Kao ve Wan (2017), enerji tüketimi ile ekonomik büyüme arasındaki ilişkileri, Tayvan'ın 1982:Q1-2014:Q4 dönemi verilerini kullanarak analiz etmiştir. VECM yöntemiyle yaptıkları nedensellik analizinde; enerji tüketiminden çıktıya doğru bir nedensellik ilişkisi tespit etmişlerdir.

Malik ve Masih (2017), enerji tüketimi, finansal gelişme ve ekonomik büyüme arasındaki ilişkileri, Malezya'nın 1971-2014 dönemi verilerini kullanarak, ARDL yöntemiyle araştırmışlar ve enerji tüketiminin, finansal gelişme ve ekonomik büyüme tarafindan kısa dönemde de uzun dönemde de etkilendiğini ve nüfus ile enerji tüketimi arasında uzun dönemde güçlü bir ilişki olduğunu tespit etmişlerdir. Guo (2018), enerji tüketimi ile ekonomik büyüme arasındaki ilişkileri, Çin ekonomisinde 1978-1991 ve 1992-2016 dönemleri için VECM yöntemiyle ayrı ayrı analiz etmiştir. Enerji tüketiminden ekonomik büyümeye doğru güçlü bir nedensellik ilişkisi belirlemiştir. Mukhtarov vd. (2018), finansal gelişmenin enerji tüketimi üzerindeki etkilerini, Azerbaycan ekonomisinin 1992-2015 dönemi için analiz etmiştir. Çalışma sonucunda; finansal gelişmedeki $\% 1$ 'lik artışın ekonomik büyümeyi $\% 0,19$, enerji tüketimini $\% 0,12$ oranında artırdığ1 tespit edilmiştir. Uslu (2018), gelişmekte olan 21 ülkede enerji tüketimiyle ekonomik büyüme arasındaki ilişkileri, 1990-2014 dönemi için panel veri analizi yöntemleriyle incelemiştir. Değişkenler arasındaki nedensellik ilişkileri; Dumitrescu ve Hurlin (2012) panel nedensellik testi ile sınanmış ve bu ülkelerde, ekonomik büyüme ile enerji tüketimi arasında karşllklı nedensellik ilişkilerinin olduğu bulunmuştur. Seriler 
arasındaki uzun ve kısa dönem analizleri Panel DOLS yöntemiyle gerçekleştirilmiş ve enerji tüketimi \%1 arttı̆̆ında, ekonomik büyümenin \%1,13 arttığ1, ekonomik büyüme \%1'lik arttı̆̆ındaysa bu ülkelerde kişi başına düşen enerji tüketiminin \%0,45 oranında arttığ1 tespit edilmiştir. Erataş Sönmez ve Sağlam (2019), yükselen piyasa ekonomilerinde finansal gelişme ve ekonomik büyüme arasındaki nedensellik ilişkilerini, 1980-2016 dönemi için panel veri analizi yöntemleriyle analiz etmiştir. Seriler arasındaki nedensellik ilişskileri; Hurlin ve Dumetriscu (2012) testi ile incelenmiş ve finansal gelişmeden, ekonomik büyümeye doğru tek yönlü bir nedensellik ilişkisinin var olduğu belirlenmiştir. Solarin vd. (2019), ICT, finansal gelişme, ekonomik büyüme ve elektrik tüketimi arasındaki ilişkileri, Malezya’nın 1990- 2015 dönemi verilerini kullanarak incelemiş ve ICT, finansal gelişme ve ekonomik büyümenin, elektrik enerjisi kullanımı üzerinde pozitif etkilerinin olduğu belirlenmiştir. Rahmani (2019), yenilenebilir enerji tüketimi ile ekonomik büyüme arasındaki ilişkileri, Türkiye'nin 1970-2016 dönemi verilerini kullanarak analiz etmiş ve yenilenebilir enerji tüketimi ile ekonomik büyüme arasında negatif ve istatistiksel olarak anlamlı bir ilişkinin olduğu görülmüştür. Ayrıca Granger nedensellik testinde yenilenebilir enerji tüketimi ile ekonomik büyüme arasında herhangi bir nedensellik ilişkisinin olmadığı belirlenmiştir. Aydın (2019), kırılgan beşli ülkelerinde finansal gelişme ile ekonomik büyüme arasındaki ilişkileri, 1992-2016 dönemi için panel veri analiziyle araştırmış ve finansal gelişme ile ekonomik büyüme arasında pozitif ilişkilerin olduğu tespit edilmiştir. Tutgun (2019), finansal gelişme ve enerji tüketiminin, ekonomik büyüme üzerindeki etkilerini, Türkiye'nin 1961-2014 dönemi verilerini kullanarak, ARDL Sınır Testi yaklaşımıyla analiz etmiştir. Finansal gelişmeyi; geniş para arzı (M2) ve özel sektöre verilen krediler ile ölçen yazar, finansal gelişme ve enerji tüketiminin, ekonomik büyümeyi artırdığını belirlemiştir. Gelişmekte olan ülkeler için yapılmış finansal gelişme, enerji tüketimi ve ekonomik büyüme konulu çalsşmaların kısa özeti Tablo 2'de yer almaktadır.

Tablo 2. Gelismekte Olan Ülkeler İ̧̧in Yapılmuş Callssmalarn Özeti

\begin{tabular}{|c|c|c|c|c|}
\hline $\begin{array}{l}\text { Yazar(lar) ve } \\
\text { Yayin Y1l1 }\end{array}$ & $\ddot{U l k e}$ & Dönem & Yöntem & Bulgular \\
\hline Özata (2010) & Türkiye & $1970-2008$ & $\begin{array}{l}\text { Granger } \\
\text { nedensellik testi ve } \\
\text { VECM analizi }\end{array}$ & $\begin{array}{l}\text { Milli gelirdeki } \% 1 \text { 'lik artışın, enerji tüketimini } \% 0,97 \text { oranında artırdığını } \\
\text { bulmuştur. Enerji tüketimindeki } \% 1^{\prime} l i k \text { artışın ise milli geliri } \% 0,57 \\
\text { oranında artırdığı görülmüştür. }\end{array}$ \\
\hline Dumrul (2011) & Türkiye & $1950-2007$ & $\begin{array}{l}\text { Sinır Testi ve } \\
\text { ARDL yöntemi }\end{array}$ & $\begin{array}{l}\text { Enerji tüketimindeki } \% 1 \text { 'lik artışı, ekonomik büyümeyi } \% 0,51 \text { oranında } \\
\text { artırdığ1 tespit edilmiştir. }\end{array}$ \\
\hline $\begin{array}{l}\text { Bozoklu ve } \\
\text { Yilanc1 (2013) }\end{array}$ & $\begin{array}{l}\text { Gelişmekte } \\
\text { Olan Ülkeler }\end{array}$ & $1988-2011$ & $\begin{array}{l}\text { Dumitrescu ve } \\
\text { Hurlin (2012) } \\
\text { panel nedensellik } \\
\text { testi }\end{array}$ & $\begin{array}{l}\text { Finansal gelişmenin, ekonomik büyümenin belirgin biçimde nedenseli } \\
\text { olduğu bulunmuştur. }\end{array}$ \\
\hline Özcan (2013) & Türkiye & $1987: 1-2012: 4$ & VECM yöntemi & $\begin{array}{l}\text { Finansal gelişme ile ekonomik büyüme arasında uzun dönemli, finansal } \\
\text { derinlik göstergeleri ile ekonomik büyüme arasında kısa dönemli ve } \\
\text { karşılıklı nedensellik ilişkileri belirlenmiştir. }\end{array}$ \\
\hline Hayaloğlu (2015) & $\begin{array}{l}\text { Kirilgan beşli } \\
\text { ülkeleri }\end{array}$ & $1990-2012$ & $\begin{array}{l}\text { Dinamik panel veri } \\
\text { analizi }\end{array}$ & $\begin{array}{l}\text { Bu ülkelerde finansal gelişmişlik düzeyi ile ekonomik büyüme arasında } \\
\text { pozitif yönlü bir ilişkinin var olduğu tespit edilmiştir. }\end{array}$ \\
\hline $\begin{array}{l}\text { Doğan ve Değer } \\
(2016)\end{array}$ & Hindistan & $1970-2013$ & $\begin{array}{l}\text { Granger } \\
\text { nedensellik testi }\end{array}$ & $\begin{array}{l}\text { Ekonomik büyümeden enerji tüketimine doğru bir nedensellik ilişkisi } \\
\text { bulurken, enerji tüketiminden ekonomik büyümeye doğru bir ilişki } \\
\text { görülmemiştir. }\end{array}$ \\
\hline Wan (2017) & Tayvan & $\begin{array}{l}\text { 1982:Q1- } \\
\text { 2014:Q4 }\end{array}$ & VECM yöntemi & Enerji tüketiminden çıktıya doğru bir nedensellik ilişkisi tespit edilmiştir. \\
\hline $\begin{array}{l}\text { Malik ve Masih } \\
\text { (2017) }\end{array}$ & Malezya & $1971-2014$ & ARDL & $\begin{array}{l}\text { Enerji tüketiminin, finansal gelişme ve ekonomik büyüme tarafindan kısa } \\
\text { dönemde de uzun dönemde de etkilendiğini ve nüfus ile enerji tüketimi } \\
\text { arasında uzun dönemde güçlü bir ilișki olduğunu belirlemişlerdir. }\end{array}$ \\
\hline Guo (2018) & Çin & $1978-2016$ & VECM yöntemi & $\begin{array}{l}\text { Enerji tüketiminden ekonomik büyümeye doğru güçlü bir nedensellik } \\
\text { ilişkisi belirlenmiştir. }\end{array}$ \\
\hline $\begin{array}{l}\text { Mukhtarov vd. } \\
(2018)\end{array}$ & Azerbaycan & $1992-2015$ & VECM yöntemi & $\begin{array}{l}\text { Finansal gelişmedeki } \% 1^{\prime} \text { lik artışın ekonomik büyümeyi } \% 0,19 \text {, enerji } \\
\text { tüketimini } \% 0,12 \text { oranında artırdığ tespit edilmiştir }\end{array}$ \\
\hline Uslu (2018) & $\begin{array}{l}\text { Gelişmekte } \\
\text { olan } 21 \text { ülke }\end{array}$ & $1990-2014$ & $\begin{array}{l}\text { Dumitrescu ve } \\
\text { Hurlin (2012) } \\
\text { panel nedensellik } \\
\text { testi, Panel DOLS }\end{array}$ & $\begin{array}{l}\text { Ekonomik büyüme ile enerji tüketimi arasında karşılıklı nedensellik } \\
\text { ilişkilerinin olduğu bulunmuştur. Enerji tüketimi } \% 1 \text { arttığında, } \\
\text { ekonomik büyümenin } \% 1,13 \text {, ekonomik büyüme } \% 1 \text { 'lik arttığındaysa kişi } \\
\text { başına düşen enerji tüketiminin } \% 0,45 \text { oranında arttığ } 1 \text { tespit edilmiştir. }\end{array}$ \\
\hline $\begin{array}{l}\text { Erataş Sönmez } \\
\text { ve Sağlam (2019) }\end{array}$ & $\begin{array}{l}\text { Yükselen piyasa } \\
\text { ekonomileri }\end{array}$ & $1980-2016$ & $\begin{array}{l}\text { Hurlin ve } \\
\text { Dumetriscu (2012) }\end{array}$ & $\begin{array}{l}\text { Finansal gelişmeden, ekonomik büyümeye doğru tek yönlü bir } \\
\text { nedensellik ilişkisi belirlenmiștir. }\end{array}$ \\
\hline $\begin{array}{l}\text { Solarin vd. } \\
(2019)\end{array}$ & Malezya & 1990- 2015 & $\begin{array}{l}\text { Toda-Yamamoto } \\
\text { nedensellik testi }\end{array}$ & $\begin{array}{l}\text { ICT, finansal gelişme ve ekonomik büyümenin, elektrik enerjisi kullanımı } \\
\text { üzerinde pozitif etkilerinin olduğu belirlenmiştir. }\end{array}$ \\
\hline Rahmani (2019) & Türkiye & $1970-2016$ & $\begin{array}{l}\text { Granger } \\
\text { nedensellik testi }\end{array}$ & $\begin{array}{l}\text { Yenilenebilir enerji tüketimi ile ekonomik büyüme arasında herhangi bir } \\
\text { nedensellik ilişkisinin olmadığı belirlenmiştir. }\end{array}$ \\
\hline Aydin (2019) & $\begin{array}{l}\text { Kirllgan beşli } \\
\text { ülkeleri }\end{array}$ & $1992-2016$ & $\begin{array}{l}\text { Panel veri } \\
\text { analiziyle }\end{array}$ & $\begin{array}{l}\text { Finansal gelişme ile ekonomik büyüme arasında pozitif ilişkilerin olduğu } \\
\text { tespit edilmiştir. }\end{array}$ \\
\hline Tutgun (2019) & Türkiye & $1961-2014$ & $\begin{array}{l}\text { ARDL Sinır Testi } \\
\text { yaklaşımı }\end{array}$ & $\begin{array}{l}\text { Finansal gelişmeyi; geniş para arzı (M2) ve özel sektöre verilen krediler ile } \\
\text { ölçen yazar, finansal gelişme ve enerji tüketiminin, ekonomik büyümeyi } \\
\text { artırdığını belirlemiştir. }\end{array}$ \\
\hline
\end{tabular}




\section{Az Gelişmiş Ülkeler İçin Yapılmış Çalışmaların Özeti}

Ndlovu (2013), Zimbabwe'de finansal gelişmenin ekonomik büyüme üzerindeki etkilerini, 1980-2011 dönemi için Granger nedensellik testiyle incelemiş ve ekonomik büyümeden finansal gelişmeye doğru tek yönlü nedensellik ilişkisi bulmuştur. Shahbaz, Abosedra ve Sbia (2013), enerji tüketimi, finansal gelişme ve ekonomik büyüme arasındaki ilișkileri, Lübnan'n 1993:M01-2010:M12 dönemi verilerini kullanarak, zaman serisi analizi yöntemiyle araştırmış ve finansal gelişme ve enerji tüketiminin ekonomik büyümeye katkı sağladığını tespit etmiştir. Ayrıca ekonomik büyüme ve finansal gelişmenin Lübnan'da enerji tüketimini artırdığı da görülmüştür. Munyanyi (2017), finansal gelişme ile ekonomik büyüme arasındaki ilişkileri Zimbabwe'nin 1965-2015 dönemi verilerini kullanarak, zaman serisi analiziyle incelemiş, Granger nedensellik testinde; bu değişkenler arasında herhangi bir nedensellik ilişkisinin olmadığını belirlemiştir. Mevduat modelinde yer alan seriler arasında eşbütünleşme ilişkisinin var olduğu görülmüşs, yapılan TodaYamamoto nedensellik testinde milli gelirden banka kredilerine doğru bir nedensellik ilişkisinin olduğu belirlenmiștir. Bist (2018), finansal gelișme ile ekonomik büyüme arasındaki ilișkileri, 16 tane fakir Afrika ülkesinin 1995-2014 dönemi verilerini kullanarak, Panel DOLS ve Panel FMOLS yöntemleriyle yaptı̆g1 analizleri sonucunda; bu ülkelerde finansal gelişmenin, ekonomik büyüme üzerinde pozitif ve istatistiksel olarak anlamlı bir etkisinin olduğunu belirlemiştir. Az gelişmiş ülkeler için yapılmış finansal gelişme, enerji tüketimi ve ekonomik büyüme konulu çalışmaların kısa özeti Tablo 3'te yer almaktadır.

Tablo 3. Az Gelişmiş Ülkeler Ị̧̇in Yapılmuş Çalşsmalarm Özeti

\begin{tabular}{|c|c|c|c|c|}
\hline $\begin{array}{l}\text { Yazar(lar) ve } \\
\text { Yayin Yili }\end{array}$ & $\ddot{U l k e}$ & Dönem & Yöntem & Bulgular \\
\hline Ndlovu (2013) & Zimbabwe & 1980-2011 & $\begin{array}{l}\text { Granger } \\
\text { nedensellik testi }\end{array}$ & $\begin{array}{l}\text { Ekonomik büyümeden finansal gelişmeye doğru tek yönlü } \\
\text { nedensellik ilişkisi bulunmuştur. }\end{array}$ \\
\hline $\begin{array}{l}\text { Shahbaz, Abosedra ve } \\
\text { Sbia (2013) }\end{array}$ & Lübnan & $\begin{array}{l}\text { 1993:M01- } \\
\text { 2010:M12 }\end{array}$ & ARDL Sinır Testi & $\begin{array}{l}\text { Finansal gelişme ve enerji tüketiminin ekonomik büyümeye katkı } \\
\text { sağladığını tespit edilmiştir. Ayrıca ekonomik büyüme ve finansal } \\
\text { gelişmenin Lübnan'da enerji tüketimini artırdığı da görülmüştür. }\end{array}$ \\
\hline Munyanyi (2017) & Zimbabwe & $1965-2015$ & $\begin{array}{l}\text { Granger } \\
\text { nedensellik testi }\end{array}$ & $\begin{array}{l}\text { Finansal gelişme ile ekonomik büyüme arasında erhangi bir } \\
\text { nedensellik ilişkisinin olmadığını belirlemiştir. }\end{array}$ \\
\hline Bist (2018) & $\begin{array}{l}16 \text { tane fakir } \\
\text { Afrika ülkesi }\end{array}$ & 1995-2014 & $\begin{array}{l}\text { Panel DOLS ve } \\
\text { Panel FMOLS }\end{array}$ & $\begin{array}{l}\text { Bu ülkelerde finansal gelişmenin, ekonomik büyüme üzerinde } \\
\text { pozitif ve istatistiksel olarak anlaml bir etkisinin olduğu } \\
\text { belirlenmiştir. }\end{array}$ \\
\hline
\end{tabular}

Literatürde yer alan çalısmalara bakıldığında; genellikle enerji tüketimi ve ekonomik büyüme ve finansal gelişme ve ekonomik büyüme arasındaki ilişkiler üzerinde durulduğu, enerji tüketimi ile finansal gelişme arasındaki ilişkinin görece daha az araştırıldı̆̆ı görülmektedir. Gelişmiş ülkelerden yapılan araştırmalarda ekonomik büyüme ve enerji tüketimi konusunun daha eski yıllarda çalışıldığı, ancak Orta Doğu, Afrika ve Asya ülkelerinde bu konunun hala çalışılmaya devam edildiği dikkati çekmiştir. Orta Doğu ve Afrika ülkeleri için yapılan finansal gelişme-ekonomik büyüme analizlerinde, genellikle finansal gelişmenin ekonomik büyüme üzerinde yeterince etkili olmadığ belirlenmiştir. Bu durumun nedeninin; bu ülkelerde dini inançlar nedeniyle faizden ve finansal sistemden uzak durulması ve finansal sistemlerinin yeterince gelişmemiş olması olduğu değerlendirilmektedir. Yine literatür taraması yapılırken dikkati çeken bir konu da finansal gelişme, ekonomik büyüme ve enerji tüketimini bir arada inceleyen araștırma sayısının azlığıdır. Araştırmacılar genellikle bu değişkenlerin ikili bileşimleri üzerinde durmuşlardır. Yapılan çalışmalarda genellikle yapısal kırılmaları dikkate almayan analiz yöntemlerinin kullanıldığı da dikkat çekicidir. Bu çalışmada; bu üç değişken bir arada analize katılarak ve yapısal kırrlmalı analiz yöntemleri de kullanılarak, literatüre bir katkı sağlanması planlanmaktadır.

\section{Veri Seti ve Ampirik Model}

\section{Veri Seti ve Tanımlayıcı İstatistikler}

Bu çalısmada; finansal gelişme ve enerji tüketiminin ekonomik büyüme üzerindeki etkileri, Türkiye'nin 1960-2019 dönemi verileri kullanılarak incelenmiştir. Çalışmada ekonomik büyüme deģ̧̆şeeni; kişi başına düşen reel GSYH (EB) ile temsil edilmiştir. Bu amaçla World Bank (2020a)'dan alınan, 2010 yllı sabit fiyatlarıyla hesaplanmış reel değerler kullanılmıştır. Çalışmada 3 farklı açıklayıcı değişken kullanılmıştır. Finansal gelişme; çalışmada finansal gelişme göstergeleri olarak Tutgun (2019) izlenerek (a) Özel sektör reel kredi hacmi (KR) ve (b) Geniş para arzı (M2) serileri kullanılmıştır. Özel sektör kredi hacminin milli gelire oranı verileri World Bank (2020b)'den alınmıs, World Bank (2020c)'den alınan milli gelir değerleri kullanılmıştır. Bu değerler World Bank (2020d)'den alınan Tüketici Fiyatları Endeksi (TUFE, $2010=100)$ kullanılarak reel hale getirilmiştir. Geniş para arzı (M2) verileri de World Bank (2020e, 2020c, 2020d)'den alınan veriler yardımıyla reel hale getirilerek analizlerde kullanılmıştır. Enerji tüketimi: Çalısmada 
enerji tüketimi Lloyd (2017) izlenerek; kişi başına düşen petrol eşdeğeri enerji tüketimi ( $\mathrm{Kg}, E T)$ ile temsil edilmiştir. Bu verilere World Bank (2020f)'den erişilmiştir. Tüm verilerin doğal logaritmaları alınarak analizlerde kullanılmıştır. Çalışmada kullanılan veriler Tablo 4'te sistematik biçimde tanıtılmıştır.

Tablo 4. Callsmada Kullanulan Veri Seti

\begin{tabular}{|c|c|c|c|c|}
\hline Değişkenin Adı & Kisaltmasi & Açıklama & Kaynak & $\begin{array}{c}\text { Analiz Dönemi ve } \\
\text { Veri Setinin Zaman } \\
\text { Boyutu }(T)\end{array}$ \\
\hline Ekonomik Büyüme & $E B$ & $\begin{array}{l}\text { Bağımlı Değişken: } 2010 \text { yılı sabit fiyatlarıyla } \\
\text { hesaplanmış kişi başına düşen reel gayri safi yurtiçi } \\
\text { hâsıla. }\end{array}$ & $\begin{array}{l}\text { World Bank (2020a); } \\
\text { EVDS (2020a) }\end{array}$ & $1960-2019(T=60)$ \\
\hline Kredi Hacmi & $K R$ & $\begin{array}{l}\text { Bağımsız Değişken 1: Finansal gelişmenin ilk } \\
\text { göstergesi olarak. Özel sektör tarafından yurtiçinde } \\
\text { kullanılan reel kredi miktarı }\end{array}$ & $\begin{array}{l}\text { World Bank (2020b, } \\
\text { 2020c, 2020d); EVDS } \\
\text { (2020b) }\end{array}$ & $1960-2019(T=60)$ \\
\hline Para Arz1 & M2 & $\begin{array}{l}\text { Bağımsız Değişken 2: Finansal gelişmenin ikinci } \\
\text { göstergesi olarak. Geniş anlamda para arzı. }\end{array}$ & $\begin{array}{l}\text { World Bank (2020e, } \\
2020 \text { c, 2020d) }\end{array}$ & $1960-2019(T=60)$ \\
\hline Enerji Tüketimi & ET & $\begin{array}{l}\text { Bağımsız Değişken 3: Enerji tüketiminin bir } \\
\text { göstergesi olarak. Kişi başına düşen, petrol eşdeğeri } \\
\text { enerji tüketimi }(\mathrm{Kg})\end{array}$ & World Bank (2020f) & $1960-2019(T=60)$ \\
\hline
\end{tabular}

Çalışmada, tüm verilerin doğal logaritmaları alınarak analizlerde kullanılmıştır. Bu yolla, analizler sonucunda değişen varyans sorunu ile karşılaşılma riski azaltıllması ve elde edilen bulguların esneklik katsayısı (\% değişim) olarak yorumlanabilmesi amaçlanmıştır. Çalışmada kurulan ekonometrik modellerde, tam logaritmik kalıp kullanılmıştır. Veri setine ait tanımlayıcı istatistikler Tablo 5'de yer almaktadır.

Tablo 5. Veri Setine Ait Tanmlayuc Istatistikler

\begin{tabular}{|c|c|c|c|c|}
\hline Serilere Ait Özellikler & $\operatorname{LnEB}$ & LnKR & LnM2 & LnET \\
\hline Ortalama & 8.805881 & 10.13759 & 10.41286 & 6.794835 \\
\hline Ortanca & 8.78795 & 9.869583 & 10.37531 & 6.842805 \\
\hline En Büyük & 9.620394 & 13.31159 & 13.12215 & 7.541311 \\
\hline En Küçük & 8.050313 & 6.924285 & 7.106606 & 5.954466 \\
\hline Standart Sapma & 0.439051 & 1.864979 & 1.853217 & 0.444211 \\
\hline Çarpıklık & 0.166171 & 0.274021 & -0.06392 & -0.22944 \\
\hline Basılklk & 2.072538 & 2.096686 & 1.873302 & 2.034661 \\
\hline Jarque-Bera Normallik Test İstatistiği & 2.426594 & 2.790816 & 3.214475 & 2.856139 \\
\hline $\begin{array}{l}\text { Jarque-Bera Normallik Test İstatistiği } \\
\text { Olasılık Değeri }\end{array}$ & 0.297216 & 0.247732 & 0.200441 & 0.239771 \\
\hline Standart Sapmaların Kareleri Toplamı & 11.3732 & 205.2107 & 202.6303 & 11.64209 \\
\hline Gözlem Sayısı & 60 & 60 & 60 & 60 \\
\hline
\end{tabular}

Tablo 5'de yer alan değerlere göre; seriler kendi ortalama değerleri etrafinda dalgalanmaktadır. Serilerin en büyük ve en küçük değerleri arasındaki fark azdır. Bu durum; serilerdeki standart sapmanın da düşük olmasını sağlamaktadır.

\section{Ampirik Model}

Finansal gelişme ve enerji tüketiminin ekonomik büyüme üzerindeki etkilerini analiz edebilmek için Shahbaz, Abosedra ve Sbia (2013); Yildız Contuk (2015); Magazzino (2016); Malik ve Masih (2017); Çelebi Boz, Çınar ve Temelli (2017) ve Solarin vd. (2019) izlenerek aşağıdaki iktisadi modeller (Denklem 27, 28) ve bu modellerin ekonometrik formda (Denklem 29, 30) gösterimleri elde edilmiştir:

Model 1: $E B=f(K R, E T)$

Model 2: $E B=f(M 2, E T)$

Kapalı formdaki bu modellerin açık biçimleri;

Model 1: $\operatorname{LnEB}_{t}=\beta_{0}+\beta_{1} \operatorname{LnKR_{t}}+\beta_{2} \operatorname{LnET}_{t}+e_{t}$

Model 2: $\operatorname{LnE} B_{t}=\theta_{0}+\theta_{1} \operatorname{LnM} 2_{t}+\theta_{2} \operatorname{LnET}_{t}+\varepsilon_{t}$

Bu modellerde yer alan $t$; zamanı, $E B$; ekonomik büyümeyi, $K R$; kredi hacmini, $M 2$; para arzını ve $E T$; enerji tüketimini göstermektedir. $e_{t}$ ve $\varepsilon_{t}$; ekonometrik olarak sorunsuz, stokastik hata terimleri serileridir. 


\section{Ampirik Yöntem ve Bulgular}

\section{Yapısal Kırılmalı Birim Kök Testleri}

Seride yapısal kırılmalar varken, bunları dikkate almaksızın yapılan birim kök testleri, hatalı sonuçlar verebilmektedir (Perron, 2017, s. 1-2). Yapısal kırılmalı birim kök testleri; dıştan verilen veya test yöntemi tarafindan içsel olarak belirlenen yapısal kırılma tarihlerini göz önünde bulundurarak, her bir dönem için ayrı ayrı birim kök sınaması yapmakta ve bunların genel sonucuna göre serinin durağanlı̆̆ hakkında bir karar vermektedir (Gujarati ve Porter, 2012, s. 758). Yapısal kırilmalı birim kök testleri arasında en yaygin kullanılanlardan biri; Vogelsang ve Perron (1998) tarafindan geliştirilen yapısal kırılmalı birim kök testidir. Bu yöntem; sabit terimde ve/veya trendde bir tane yapısal kırlmaya izin verilmekte ve yapısal kirılma tarihi içsel olarak belirlenmektedir. Bu amaçla kullanılan denklem:

$$
Y_{t}=\mu+\beta t+\theta D U_{t}\left(T_{b}\right)+\gamma D T_{t}\left(T_{b}\right)+\omega D_{t}\left(T_{b}\right)+\varphi Y_{t-1}+\sum_{i=1}^{m} c_{i} \Delta Y_{t-i}+u_{t}
$$

şeklindedir. Burada, yapısal kırılma tarihlerini belirleyebilmek için kullanılan kukla değişkenler;

$$
D U_{t}\left(T_{b}\right)= \begin{cases}1, & t \geq T_{b} \text { ise } \\ 0, & t<T_{b} \text { ise }\end{cases}
$$

Sabit terimdeki yapısal kırılmaları temsil eden kukla değişken;

$$
D T_{t}\left(T_{b}\right)= \begin{cases}1, & t \geq T_{b} \text { ise } \\ t-T_{b}+1, & t<T_{b} \text { ise }\end{cases}
$$

Trenddeki yapısal kırılmaları temsil eden kukla değişken;

$$
D_{t}\left(T_{b}\right)= \begin{cases}1, & t=T_{b} \text { ise } \\ 0, & t \neq T_{b} \text { ise }\end{cases}
$$

şeklindedir. Testin $H_{0}$ hipotezi; " $\varphi=1$ Yapısal kırılma altında seri dură̆an değildir" şeklindedir. Bu

\begin{tabular}{|c|c|c|c|c|c|c|c|c|}
\hline \multirow[b]{3}{*}{ Seri } & \multicolumn{4}{|c|}{ Düzey Değerleri } & \multicolumn{4}{|c|}{ Birinci Farkları } \\
\hline & \multicolumn{2}{|c|}{ Sabitli } & \multicolumn{2}{|c|}{ Sabitli ve Trendli } & \multicolumn{2}{|c|}{ Sabitli } & \multicolumn{2}{|c|}{ Sabitli ve Trendli } \\
\hline & $\begin{array}{c}\text { Test } \\
\text { Istatistiği }\end{array}$ & $\begin{array}{c}\text { Yap1sal } \\
\text { K1r1lma } \\
\text { Tarihi }\end{array}$ & $\begin{array}{c}\text { Test } \\
\text { Istatistiği }\end{array}$ & $\begin{array}{c}\text { Yapısal } \\
\text { Kirılma Tarihi }\end{array}$ & $\begin{array}{c}\text { Test } \\
\text { Istatistiği }\end{array}$ & $\begin{array}{c}\text { Yapisal Kirilma } \\
\text { Tarihi }\end{array}$ & $\begin{array}{c}\text { Test } \\
\text { Istatistiği }\end{array}$ & $\begin{array}{c}\text { Yapisal Kırılma } \\
\text { Tarihi }\end{array}$ \\
\hline $\operatorname{LnEB}$ & $-2,04(0,98)$ & 2002 & $-4,87 * *(0,04)$ & 2010 & $-7,51 * * *(0,00)$ & 2009 & - & - \\
\hline LnKR & $-1,97(0,98)$ & 2020 & $-4,06(0,33)$ & 2004 & $-9,32 * * *(0,00)$ & 2001 & $-9,48^{* * *}(0,00)$ & 2001 \\
\hline LnM2 & $-1,67(0,99)$ & 1963 & $-3,24(0,82)$ & 2016 & $-9,16^{* * *}(0,00)$ & 1980 & $-9,09 * * *(0,00)$ & 1980 \\
\hline LnET & $-1,94(0,98)$ & 2002 & $-4,60 *(0,09)$ & 1971 & $-7,87 * * *(0,00)$ & 1979 & - & - \\
\hline
\end{tabular}
hipotezi test etmek için gerekli olan kritik değerler; Vogelsang (1993) çalışmasında verilmiştir. Vogelsang ve Perron (1998) birim kök testi sonuçları Tablo 6'da yer almaktadır.

Tablo 6. Vogelsang ve Perron (1998) Tek Yapısal Kurlmalı Birim Kök Testi Sonuclar

Not: Optimum gecikme uzunlukları Akaike Bilgi Kriteri yardımıyla belirlenmiştir. Bu işlemlerde, max. gecikme uzunluğu 3 olarak alınmıştır. *** ve **; serinin $\% 1$ ve $\% 5$ anlamlılık düzeyinde durağan olduğunu göstermektedir. Parantez içinde yer alanlar, olasılık değerleridir. Düzey değerinde durağan olan serilere birinci farkta birim kök sınaması yapılmamıştır.

Tablo 6'daki sonuçlara göre; $L n E B$ ve $L n E T$ serileri düzey değerinde durağan iken $L n K R$ ve $L n M 2$ serileri birinci farkta durağandır. Çalışmada ayrıca Lee ve Strazicich (2003) iki yapısal kırılmalı birim kök testi de kullanılmıştır. Bu yöntemde de yapısal kırılma tarihleri içsel olarak belirlenebilmekte ve yapısal kırılma tarihleri, birim kök parametresinin $t$ istatistiğinin en küçük değerini aldığ1 noktalar olarak alınmaktadır. Yazarlar çalışmalarında Perron (1989) tarafindan kullanılan Model A ve Model C'yi kullanmışlar, bu modelleri iki yapısal kırılmaya uygun şekilde revize etmişlerdir.

$\operatorname{Model}(A): \quad y_{t}=\mu_{1}+\beta t+\left(\mu_{2}-\mu_{1}\right) D U_{1 t}+\left(\mu_{3}-\mu_{2}\right) D U_{2 t}+\varphi y_{t-1}+\sum_{t=1}^{p} \delta_{t} \Delta y_{t-1}+e_{t}$

$\operatorname{Model}(C): \quad y_{t}=\mu_{1}+\beta_{1} t+\left(\mu_{2}-\mu_{1}\right) D U_{1 t}+\left(\mu_{3}-\mu_{2}\right) D U_{2 t}+\left(\beta_{2}-\beta_{1}\right) D T_{1 t}+\left(\beta_{3}-\beta_{2}\right) D T_{2 t}+\varphi y_{t-1}+\sum_{t=1}^{p} \delta_{t} \Delta y_{t-1}+e_{t}$

Burada $D U_{1 t}, D U_{2 t}, D T_{1}$ ve $D T_{2} ; T B_{1}$ ve $T B_{2}$ dönemlerinde meydana gelen yapisal kır1malar1 temsil eden kukla değişkenlerdir. Bu testin $H_{0}$ hipotezi; "Yapısal kurlmalar altında seri durăgan değildir" şeklindedir. Lee ve Strazicich (2003) iki yapısal kırılmalı birim kök testi sonuçları Tablo 7'de yer almaktadır. 
Tablo 7. Lee ve Strazicich (2003) İki Yapısal Kımlmalı Birim Kök Testi Sonuçlar

\begin{tabular}{|c|c|c|c|c|}
\hline \multirow{2}{*}{ Seri } & \multicolumn{2}{|c|}{ Model AA } & \multicolumn{2}{|c|}{ Model CC } \\
\hline & Test İstatistiği & Kırılma Tarihi & Test İstatistiği & Kırılma Tarihi \\
\hline$L n E B$ & $-4,39 * *$ & $1978 ; 2010$ & $-5,77 * *$ & $1977 ; 2008$ \\
\hline $\operatorname{LnKR}$ & $-2,41$ & $2004 ; 2006$ & $-4,50$ & $1971 ; 2002$ \\
\hline LnM2 & $-2,75$ & 1980; 2009 & $-4,25$ & $1971 ; 2002$ \\
\hline $\operatorname{LnET}$ & $-3,75$ & $1974 ; 2000$ & $-4,89$ & $1970 ; 1980$ \\
\hline$\triangle L n K R$ & $-4,27 * *$ & $1978 ; 1996$ & $-7,82 * * *$ & 1965; 2001 \\
\hline$\triangle L n M 2$ & $-3,28$ & $1978 ; 1998$ & $-7,82^{* * *}$ & $1965 ; 2002$ \\
\hline$\triangle L n E T$ & $-6,51 * * *$ & 1977; 1980 & $-7,76^{* * *}$ & 1973; 1977 \\
\hline \multicolumn{5}{|c|}{ Kritik Değerler } \\
\hline$\% 1$ & \multicolumn{2}{|c|}{$-4,545$} & \multicolumn{2}{|c|}{$-5,823$} \\
\hline$\% 5$ & \multicolumn{2}{|c|}{$-3,842$} & \multicolumn{2}{|c|}{$-5,286$} \\
\hline$\% 10$ & \multicolumn{2}{|c|}{$-3,504$} & \multicolumn{2}{|c|}{$-4,989$} \\
\hline
\end{tabular}

Not: LS'de Model AA; sabit terimde, Model CC; sabit terimde ve trendde iki tane yapısal kırllmaya izin vermektedir. ${ }^{* * *},{ }^{* *} ; \% 1$ ve $\% 5$ anlamlılık düzeyinde durağanlığı ifade etmektedir. $\Delta$; serinin birinci farkını göstermektedir.

Tablo 7'deki bulgulara göre; $L n E B$ serisinin düzeyde durağan yani $\mathrm{I}(0)$ olduğuna karar verilmiştir. $L n K R, L n M 2$ ve LnET serilerin ise düzey değerlerinde değil, birinci farklarında durağan, yani I(1) oldukları belirlenmiştir. Çalışmadaki analiz dönemi uzun olduğu ve serilerde ikiden fazla yapısal kırılma olabileceği düşüncesinden hareketle, Carrion-i-Silvestre vd. (2009) çoklu yapısal kırılmalı birim kök testinden de yararlanılmıştır. $\mathrm{Bu}$ test; serideki beş taneye kadar yapısal kırılmanın varluğını göz önünde bulundurabilmekte ve yapısal kırrlma tarihlerini içsel olarak belirleyebilmektedir. Carrion-i-Silvestre vd. (2009) testinde beş farklı test istatistiği geliştirilmiştir:

$$
\begin{aligned}
& P_{T}(\lambda)=\{S(\bar{\alpha}, \lambda)-\bar{\alpha} S(1, \lambda)\} / s^{2}(\lambda) \\
& M P_{T}(\lambda)=\left[c^{-2} T^{-2} \sum_{t=-}^{T} y_{t-1}^{2}+(1-\bar{c}) T^{-1} y_{T}^{2}\right] / s(\lambda)^{2} \\
& M Z_{\alpha}(\lambda)=\left(T^{-1} y_{T}^{2}-s(\lambda)^{2}\right)\left(2 T^{-2} \sum_{t=-}^{T} y_{t-1}^{2}\right)^{-1} \\
& M S B(\lambda)=\left(s(\lambda)^{-2} T^{-2} \sum_{t=-}^{T} y_{t-1}^{2}\right)^{-1 / 2}\left(T^{-1} y_{T}^{2}-s(\lambda)^{2}\right)\left(4 s(\lambda) T^{-2} \sum_{t=-}^{T} y_{t-1}^{2}\right)^{-1 / 2} \\
& M Z_{t}(\lambda)=\left(T^{2}\right.
\end{aligned}
$$

Denklem (39 ve 41)'de yer alan $M Z_{\alpha}$ ve $M Z_{t}$ testleri, ADF ve PP grubundan olup, $H_{0}$ hipotezleri; "Seri yapısal kirlmalar altında birim kök içermektedir" şeklinde iken Denklem (37, 38 ve 40)'daki $P_{T}, M S B$ ve $M P_{T}$ testleri, KPSS grubundan olup, $H_{0}$ hipotezleri "Seri yapısal kirlmalar altında birim kök içermemektedir"

\begin{tabular}{|c|c|c|c|c|c|c|}
\hline Seri & $P_{T}$ & $M P_{T}$ & $M Z_{\alpha}$ & $M S B$ & $M Z_{t}$ & $\begin{array}{c}\text { Yapısal Kırılma } \\
\text { Tarihleri }\end{array}$ \\
\hline$\overline{L n E B}$ & $8,42(5,07)$ & $8,28(5,07)$ & $-21,43(-30,04)$ & $0,14(0,13)$ & $-3,16(-3,85)$ & $1977 ; 1980 ; 2001$ \\
\hline $\operatorname{LnKR}$ & $13,06(6,75)$ & $12,65(6,75)$ & $-15,82(-29,84)$ & $0,17(0,13)$ & $-2,81(-3,85)$ & $1962 ; 2003 ; 2013$ \\
\hline LnM2 & $16,84(6,76)$ & $16,02(6,76)$ & $-12,51(-30,00)$ & $0,19(0,12)$ & $-2,49(-3,86)$ & $1962 ; 2003 ; 2008$ \\
\hline $\operatorname{LnET}$ & $8,08(5,90)$ & $8,31(5,90)$ & $-22,72(-29,97)$ & $0,14(0,13)$ & $-3,28(-3,82)$ & $1970 ; 1977 ; 1979$ \\
\hline$\triangle L n E B$ & $4,98 * *(5,87)$ & $4,51 * *(5,87)$ & $-28,16 * *(-22,00)$ & $0,13 * *(0,15)$ & $-3,74 * *(-3,31)$ & $2008 ; 2010$ \\
\hline$\triangle L n K R$ & $7,08 * *(7,55)$ & $7,30 * *(7,55)$ & $-28,84 * *(-28,36)$ & $0,1314 * *(0,1315)$ & $-3,79 * *(-3,75)$ & $1962 ; 1990$ \\
\hline$\triangle L n M 2$ & $7,01 * *(7,55)$ & $7,23 * *(7,55)$ & $-28,98 * *(-28,36)$ & $0,1313 * *(0,1315)$ & $-3,80 * *(-3,75)$ & $1962 ; 1990$ \\
\hline$\triangle L n E T$ & $6,42 * *(6,83)$ & $6,28^{* *}(6,83)$ & $-28,54 * *(-26,22)$ & $0,1322 * *(0,1380)$ & $-3,77 * *(-3,62)$ & $1980 ; 2015$ \\
\hline
\end{tabular}
biçimindedir. Bu hipotezleri test edebilmek için gereken kritik değerler, bootstrap döngüsü yardımıyla elde edilmektedir. Carrion-i-Silvestre vd. (2009) beş yapısal kırılmalı birim kök testi sonuçları Tablo 8'de yer almaktadır.

Tablo 8. Carrion-i-Silvestre vd. (2009) Bess Yapısal Kurlmah Birim Kök Testi Sonucları

Not: Parantez içinde yer alan değerler; 1000 yinelemeli bootstrap döngüsü ile ilde edilmiş (\%5 anlamllık düzeyine sahip) kritik değerlerdir. **; İlgili serinin $\% 5$ anlamlllık düzeyinde durağan olduğunu göstermektedir.

Tablo 8'deki bulgulara göre; düzey değerlerinde hiçbir seri durağan değildir. Birinci farklarında ise bütün serilerin durağan oldukları görülmüsstür. Bütün birim kök testlerinden elde edilen sonuçlar birlikte değerlendirildiğinde; genel olarak tüm serilerin I(1) olduklarına karar verilmiştir. 


\section{Yapısal Kırılmalı Eşbütünleşme Testleri}

Çalışmada seriler arasında eşbütünleşme ilişkisinin varlı̆̆ı, yapısal kırılmalı Gregory ve Hansen (1996) tek kırılmalı eşbütünleşme testi ve Maki (2012) çoklu yapısal kırılmalı eşbütünleşme testi ile incelenmiştir. Gregory ve Hansen (1996), testlerini geliştirirken; $Y$ ve $X$ şeklindeki iki değişkeni temel almışlar ve $Y \sim I(d)$ ve $X \sim I(d)$ iken, Denklem (42) oluşturmuşlardır:

$Y_{t}=\beta_{1}+\alpha_{1} X_{t}+e_{t}$

Bu denklemde $Y$ ile $X$ arasında eşbütünleşme olabilmesi için Engle ve Granger (1987)'de olduğu gibi $e_{t}$ serisinin durağanlığına odaklanılmıştır. Gregory ve Hansen (1996), yapısal kırılmalı eşbütünleşme sınaması yapabilmek için üç farklı test yöntemi (model) geliştirmişlerdir:

Model C: $Y_{t}=\beta_{1}+\left(\beta_{2}-\beta_{1}\right) \varphi_{t \tau}+\alpha_{1} X_{t}+e_{t}$

Model $C / T: Y_{t}=\beta_{1}+\left(\beta_{2}-\beta_{1}\right) \varphi_{t \tau}+\gamma t+\alpha_{1} X_{t}+e_{t}$

Model $C / S: Y_{t}=\beta_{1}+\left(\beta_{2}-\beta_{1}\right) \varphi_{t \tau}+\alpha_{1} X_{t}+\left(\alpha_{2}-\alpha_{1}\right) \varphi_{t \tau} X_{t}+e_{t}$

Bu modellerden ilki (Model $C$ ); düzeyde (sabit terimde) kırrlmalı, trendsiz modeli, ikincisi (Model $C / T$ ); düzeyde kırılmalı, trendli modeli ve üçüncüsü (Model $C / S$ ); düzeyde ve eğimde kırılmalı, trendsiz modeli göstermektedir. Yapısal kırılma noktalarının tespitinde kullanılan kukla değişkenler:

$\varphi_{t \tau}= \begin{cases}0, & t \leq[n \tau] \text { ise } \\ 1, & t>[n \tau] \text { ise }\end{cases}$

Burada $n$; gözlem sayısı, $\tau$; veri setine baştan ve sondan $\% 15$ triminning (örneklem kesimi) uygulandıktan sonra geri kalan $(0.15 T, 0.85 T)$ aralı̆ında yer alan değişim noktalarını göstermektedir. $T$; toplam gözlem sayısıdır. Gregory ve Hansen (1996) yapısal kırrlmalı eşbütünleşme testinde, yapısal kırılma tarihlerinin belirlenebilmesi için, analiz dönemi boyunca her bir $\tau$ için bu modeller ardışı tahmin edilir ve elde edilen hata terimi serilerine ADF birim kök testi uygulanır. ADF test istatistiğinin en küçük olduğu tarih, yapisal kırılma tarihi olarak alınır (Narayan, 2007, s. 78). Bu testin $H_{0}$ hipotezi; "Yapısal kerrlma altunda seriler eşbütünlessik değildir" şeklindedir. Bu hipotezleri test edebilmek için gereken kritik değerler, Gregory ve Hansen (1996)'da verilmiştir. Gregory ve Hansen (1996) yapısal kırrlmalı eşbütünleşme testi sonuçları Tablo 9'da yer almaktadır.

Tablo 9. Gregory ve Hansen (1996) Tek Yapısal Kurlmah Eşbütünleşme Testi Sonuclar

\begin{tabular}{|c|c|c|c|c|c|c|c|c|c|}
\hline \multirow[b]{3}{*}{ Modeller } & \multirow{2}{*}{\multicolumn{3}{|c|}{$\begin{array}{c}\text { ADF Prosedürü } \\
t \text {-istatistiği }\end{array}$}} & \multicolumn{6}{|c|}{ Phillips Prosedürü } \\
\hline & & & & \multicolumn{3}{|c|}{$Z a-$ istatistiği } & \multicolumn{3}{|c|}{$Z t-$ istatistiği } \\
\hline & $\begin{array}{c}\text { Model C } \\
\text { Düzeyde } \\
\text { Kirlma }\end{array}$ & $\begin{array}{c}\text { Model C/T } \\
\text { Düzeyde Krrllma } \\
\text { Trendli }\end{array}$ & $\begin{array}{l}\text { Model C/S } \\
\text { Rejimde } \\
\text { Kirllma }\end{array}$ & $\begin{array}{c}\text { Model C } \\
\text { Düzeyde } \\
\text { Kırlma }\end{array}$ & $\begin{array}{c}\text { Model C/T } \\
\text { Düzeyde } \\
\text { Kirtlma } \\
\text { Trendli }\end{array}$ & $\begin{array}{c}\text { Model C/S } \\
\text { Rejimde } \\
\text { Kirllma }\end{array}$ & $\begin{array}{c}\text { Model } C \\
\text { Düzeyde } \\
\text { Kırlma }\end{array}$ & $\begin{array}{c}\text { Model C/T } \\
\text { Düzeyde } \\
\text { KtrIlma } \\
\text { Trendli }\end{array}$ & $\begin{array}{c}\text { Model C/S Rejimde } \\
\text { Kirtlma }\end{array}$ \\
\hline Model 1 & $\begin{array}{c}-4,83^{*} \\
(0) \\
{[1973]}\end{array}$ & $\begin{array}{c}-4,28 \\
(2) \\
{[1975]}\end{array}$ & $\begin{array}{c}-4,51 \\
(0) \\
{[1971]}\end{array}$ & $\begin{array}{l}-35,05 \\
{[1973]}\end{array}$ & $\begin{array}{l}-28,03 \\
{[1974]}\end{array}$ & $\begin{array}{l}-31,86 \\
{[1971]}\end{array}$ & $\begin{array}{l}-4,90^{*} \\
{[1973]}\end{array}$ & $\begin{array}{c}-4,26 \\
{[1973]}\end{array}$ & $\begin{array}{c}-4,54 \\
{[1971]}\end{array}$ \\
\hline Model 2 & $\begin{array}{c}-4,83^{*} \\
(0) \\
{[1973]}\end{array}$ & $\begin{array}{c}-6.12 * * * \\
(3) \\
{[1976]}\end{array}$ & $\begin{array}{c}-4,51 \\
(0) \\
{[1971]}\end{array}$ & $\begin{array}{l}-35,05 \\
{[1973]}\end{array}$ & $\begin{array}{l}-36,05 \\
{[1978]}\end{array}$ & $\begin{array}{l}-31,86 \\
{[1971]}\end{array}$ & $\begin{array}{l}-4,90^{*} \\
{[1973]}\end{array}$ & $\begin{array}{c}-4,98 \\
{[1978]}\end{array}$ & $\begin{array}{c}-4,54 \\
{[1971]}\end{array}$ \\
\hline \multicolumn{10}{|c|}{ Kritik Değerler } \\
\hline$\% 1$ & $-5,44$ & $-5,80$ & $-5,97$ & $-57,01$ & $-64,77$ & $-68,21$ & $-5,44$ & $-5,80$ & $-5,97$ \\
\hline$\% 5$ & $-4,92$ & $-5,29$ & $-5,50$ & $-46,98$ & $-53,92$ & $-58,33$ & $-4,92$ & $-5,29$ & $-5,50$ \\
\hline$\% 10$ & $-4,69$ & $-5,03$ & $-5,23$ & $-42,49$ & $-48,94$ & $-52,85$ & $-4,69$ & $-5,03$ & $-5,23$ \\
\hline
\end{tabular}

Tablo 9'daki bulgulara göre; elde edilen test istatistikleri $(-4,83 ;-6,12 ;-4,90)$, kritik değerlerden $(-4,69$; $-5,80 ;-4,69)$ küçük olduğu için bu modellerde yer alan seriler arasında eşbütünleşme ilişkisinin var olduğuna karar verilmiştir. Bu çalışmada olduğu gibi uzun zaman boyutuna sahip analizlerde bir tek yapisal kırılmanın göz önünde bulundurulması yetersiz kalacaktır. Çünkü süre uzadıkça ülke ekonomilerini etkileyen birden fazla önemli faktör gündeme gelebilmektedir. Maki (2012) bu sorunu çözebilmek için beş taneye kadar yapısal kırılmaya izin veren ve yapısal kırılma adedini ve tarihlerini içsel olarak belirleyebilen yeni bir yapısal kırılmalı eşbütünleşme testi geliştirmiştir. Maki (2012), eşbütünleşme vektöründe birden fazla yapisal kırılma olduğunda, kendi geliştirdiği testin Gregory ve Hansen (1996) ve Hatemi-J (2008) testlerinden daha güçlü olduğunu ifade etmiştir. Maki (2012)'de kendisinden önceki araştırmacılar gibi 
baştan belirli sayıda gözlemi ayırmakta, ayırdığı bu gözlemlerle bir model tahmin etmekte ve hata terimleri serisine ait birim kök parametresinin $t$ istatistiğini elde etmektedir. Daha sonra her bir dönemi muhtemel bir yapısal kırılma tarihi olarak kukla değişkenlerle modellere dâhil edip, tahminlerini yenilemekte ve yeni $t$ istatistikleri elde etmektedir. Elde edilen bu $t$ istatistiklerinin en küçük olduğu yer ilk yapısal kırılma tarihi olarak belirlenmekte, akabinde diğer tarihler modele dahil edilerek, bir sonraki yapısal kırlma tarihi belirlenmeye çalışılmaktadır. Daha sonra belirlenen bu yapısal kırılma tarihleri kukla değişkenlerle modelde kullanilarak tahminler yapilmakta ve bu modellerin hata terimlerinin kareleri toplamları (SSR) elde edilmektedir. SSR'nin en küçük olduğu modelde yer alan yapısal kırilma adedi ve tarihleri, ideal yapısal kırılma adedi ve tarihleri olarak rapor edilmektedir. Maki (2012), çoklu yapisal kırılmalar altında eşbütünleşme sınaması yapabilmek için dört farklı model geliştirmiştir:

Model 0: $Y_{t}=\mu+\sum_{i=1}^{k} \mu_{i} D_{i, t}+\beta^{\prime} X_{t}+u_{t}$
Model 1: $Y_{t}=\mu+\sum_{i=1}^{k} \mu_{i} D_{i, t}+\beta^{\prime} X_{t}+\sum_{i=1}^{k} \beta_{i}^{\prime} X_{i} D_{i, t}+u_{t}$
Model 2: $Y_{t}=\mu+\sum_{i=1}^{k} \mu_{i} D_{i, t}+\gamma t+\beta^{\prime} X_{t}+\sum_{i=1}^{k} \beta_{i}^{\prime} X_{i} D_{i, t}+u_{t}$
Model 3: $Y_{t}=\mu+\sum_{i=1}^{k} \mu_{i} D_{i, t}+\gamma t+\sum_{i=1}^{k} \gamma_{i} t D_{i, t}+\beta^{\prime} X_{t}+\sum_{i=1}^{k} \beta_{i}^{\prime} X_{i} D_{i, t}+u_{t}$

$\mathrm{Bu}$ modellerden Model 0; sabit terimde kirlmalı, trendsiz modeli, Model 1; sabit terimde ve eğimde kırilmalı, trendsiz modeli, Model 2; sabit terimde ve eğimde kırılmalı, trendli modeli ve Model 3; sabit terimde, eğimde ve trendde kırrlmalı modeli ifade etmektedir. Maki (2012) çoklu yapısal kırrlmalı eşbütünleşme testinin $H_{0}$ hipotezi; "Yapısal kırnlma altunda seriler eşbütünleșik değildirr" şeklindedir. Bu hipotezleri test edebilmek için gereken kritik değerler, Maki (2012)'te verilmiştir. Maki (2012) yapısal kırılmalı eşbütünleşme testi sonuçları Tablo 10'da yer almaktadır.

Tablo 10. Maki (2012) Coklu Yapısal Kirlmalı Eşbütünlessme Testi Sonuçlar

\begin{tabular}{|c|c|c|c|c|}
\hline Modeller & Model 0 & Model 1 & Model 2 & Model 3 \\
\hline Modeli 1 & $\begin{array}{c}-4,12 \\
{[1976 ; 1983 ; 1992 ; 1999 ; 2012]}\end{array}$ & $\begin{array}{c}-5,95 * * \\
{[1976 ; 1998 ; 2009]}\end{array}$ & $\begin{array}{c}-6,44^{* *} \\
{[1970 ; 1979 ; 1997 ; 2006]}\end{array}$ & $\begin{array}{c}-6,43^{*} \\
{[1974 ; 2009]}\end{array}$ \\
\hline Modeli 2 & $\begin{array}{c}-6,00 * * * \\
{[1971 ; 1993]}\end{array}$ & $\begin{array}{c}-6,74 * * * \\
{[1971 ; 1993 ; 2004 ; 2012]}\end{array}$ & $\begin{array}{c}-5,09 \\
{[1979 ; 2010]}\end{array}$ & $\begin{array}{c}-6,16 \\
{[1972 ; 2003]}\end{array}$ \\
\hline \multicolumn{5}{|c|}{ Kritik Değerler } \\
\hline$\% 1$ & $-5,71$ & $-6,01$ & $-6,62$ & $-7,15$ \\
\hline$\% 5$ & $-5,21$ & $-5,51$ & $-6,09$ & $-6,65$ \\
\hline$\% 10$ & $-4,95$ & $-5,24$ & $-5,83$ & $-6,39$ \\
\hline
\end{tabular}

Not: ${ }^{* * *},{ }^{* *}$ ve $*$; ilgili modelde yer alan seriler arasında sırasıyla $\% 1, \% 5$ ve $\% 10$ anlamlılık düzeyinde eșbütünleșme ilișkisinin var olduğunu göstermektedir. [] içindekiler yapısal kırılma tarihleridir. Kritik değerler Maki (2012, s. 2013) Tablo 1'den m (açlklayıc1 değişken sayısı) $=2$ için alınmış değerlerdir.

Tablo 10'daki sonuçlara göre; her iki modelde de $H_{0}$ hipotezi en az \%10 anlamlllik düzeyinde reddedilebildiği için bu modellerde yer alan seriler arasında eşbütünleşme ilişkisinin var olduğuna karar verilmiştir. Çünkü elde edilen test istatistikleri ilgili yönteme ait kritik değerlerden daha küçüktür ve $H_{0}$ red bölgesine düşmektedir.

\section{Uzun Dönem Analiz Bulguları}

Çalışmada uzun dönem analizleri; serilerin düzey değerleri kullanılarak, FMOLS, DOLS ve CCR yöntemleriyle gerçekleştirilmiştir. Phillips ve Hansen (1990), eşbütünleşik seriler arasında EKK yöntemiyle yapılan tahminlerde karşılaşılan sapma ve içsellik sorunlarını düzelterek, FMOLS tahmincisini geliştirmiştir. Yar1 parametrik bir tahminci olan FMOLS, uzun dönem regresyonu ile bu regresyona ait stokastik hata terimi arasındaki korelasyondan kaynaklanan sapmaları elimine etmektedir. FMOLS tahmincisi asimptotik olarak sapmasızdır ve kullandığı Wald testi ve Ki-kare istatistikleri yönüyle tam etkindir. Stock ve Watson (1993), EKK'daki sapma ve içsellik sorunlarını düzeltebilmek için, bağımsız değişkenin düzey değerleriyle birlikte, farklarının gecikmeli değerlerinin ve öncül değerlerinin de modele eklenmesinin yararlı olacağını ifade etmiştir. Bu şekilde geliştirdikleri DOLS yöntemi, eşbütünleşik seriler arasındaki uzun ve kısa dönem analizlerinin yapılmasında etkin bir tahmincidir. Bu yöntem, otokorelasyon ve değişen varyans sorunlarına karşı dirençli tahminler üretebilmektedir. Bu yönüyle diğer tahmincilerden daha güçlü kabul edilmektedir 
(Esteve ve Requena, 2006, s. 118). Park (1992) tarafindan geliştirilen CCR yöntemi ise kanonik regresyonun, seriler arasındaki korelasyonun en yüksek olması esasına dayanıyor olmasıdır (Berk, 2014, s. 72). Ayrıca bu yöntem katsayıları, eşbütünleşik seriler arasındaki eşbütünleşme vektörünü de göz önünde bulundurarak tahmin etmektedir (Park, 1992, s. 120-121). Kanonik regresyon analizi yöntemi aynı zamanda değişen varyans ve otokorelasyona karşı dirençli bir tahmin yöntemidir. Uzun dönem analizleri FMOLS, DOLS ve CCR yöntemleriyle yapılmış ve ulaşılan sonuçlar Tablo 11'de sunulmuştur.

Tablo 11. Uzun Dönem Analizi Sonuclar

\begin{tabular}{|c|c|c|c|c|c|c|}
\hline \multirow{2}{*}{$\begin{array}{c}\text { Açıklayıcı } \\
\text { Değiģkenler }\end{array}$} & \multicolumn{2}{|c|}{ FMOLS } & \multicolumn{2}{|c|}{ DOLS } & \multicolumn{2}{|c|}{$C C R$} \\
\hline & Model 1 & Model 2 & Model 1 & Model 2 & Model 1 & Model 2 \\
\hline$\overline{\operatorname{LnKR}}$ & $0,14 * * *(0,00)$ & - & $0,13^{* * *}(0,00)$ & - & $0,14^{* * *}(0,00)$ & - \\
\hline $\operatorname{LnM} 2$ & & $0,14^{* *}(0,01)$ & - & $0,24 * * *(0,00)$ & - & $0,13^{* *}(0,01)$ \\
\hline $\operatorname{LnET}$ & $0,38^{* * *}(0,00)$ & $0,40 *(0,08)$ & $0,41 * * *(0,00)$ & $-0,03(0,90)$ & $0,40 * * *(0,00)$ & $0,41 *(0,07)$ \\
\hline$K_{1971}$ & - & $0,09 \quad(0,35)$ & - & $0,01(0,85)$ & - & $-0,03(0,72)$ \\
\hline$K_{1976}$ & $-0,04(0,47)$ & - & $-0,02(0,66)$ & - & $-0,07(0,40)$ & - \\
\hline$K_{1979}$ & $-0,09 \quad(0,12)$ & $-0,09(0,34)$ & $-0,06(0,38)$ & $-0,006(0,94)$ & $-0,12(0,15)$ & $-0,03(0,73)$ \\
\hline$K_{1983}$ & $-0,10 *(0,09)$ & - & $-0,07(0,18)$ & - & $-0,14(0,10)$ & - \\
\hline$K_{1993}$ & - & $-0,02(0,78)$ & - & $0,05(0,56)$ & - & $0,03(0,76)$ \\
\hline$K_{1998}$ & $0,009 \quad(0,88)$ & - & $0,02(0,67)$ & - & $-0,004(0,96)$ & - \\
\hline$K_{2004}$ & - & $-0,01(0,84)$ & - & $0,05(0,60)$ & - & $0,03(0,72)$ \\
\hline$K_{2009}$ & $-0,11^{*}(0,07)$ & - & $-0,09(0,12)$ & - & $-0,14(0,11)$ & - \\
\hline$K_{2012}$ & - & $0,005(0,95)$ & - & $-0,07(0,40)$ & - & $0,04(0,68)$ \\
\hline $\begin{array}{l}\text { Sabit } \\
\text { Terim }\end{array}$ & $4,72 * * *(0,00)$ & $4,59 * * *(0,00)$ & $4,59 * * *(0,00)$ & $6,48^{* * *}(0,00)$ & $0,64 * * *(0,00)$ & $4,56^{* * *}(0,00)$ \\
\hline \multicolumn{7}{|c|}{ Model Doğrulama Testleri } \\
\hline$\overline{R^{2}}$ & 0,99 & 0,98 & 0,99 & 0,98 & 0,99 & 0,97 \\
\hline $\bar{R}^{2}$ & 0,99 & 0,97 & 0,99 & 0,98 & 0,98 & 0,97 \\
\hline$S E R$ & 0,04 & 0,06 & 0,03 & 0,05 & 0,04 & 0,06 \\
\hline$L R V$ & 0,003 & 0,009 & 0,003 & 0,006 & 0,003 & 0,01 \\
\hline SSR & 0,09 & 0,21 & 0,05 & 0,11 & 0,10 & 0,23 \\
\hline
\end{tabular}

Tablo 11'de yer alan sonuçlara göre; FMOLS yönteminde ekonomik büyüme; $L n K R$ \%1 arttı̆gnnda \%0,14, LnM2 \%1 arttı̆̆ında \%0,14, LnET \%1 arttı̆̆ında ise Model 1'de \%0,38, Model 2'de \%0,40 artmıştır. DOLS yönteminde ekonomik büyüme; LnKR \%1 arttığında \%0,13, LnM2 \%1 arttı̆̆ında $\% 0,24$, LnET \%1 arttığında ise Model 1'de \%0,41 artmış, Model 2'de LnET'nin ekonomik büyüme üzerinden uzun dönemde istatistiksel olarak anlamlı bir etkisinin olmadığı belirlenmisștir. CCR yöntemindeyse ekonomik büyüme; LNKR \%1 arttı̆ında \%0,14, LNM2 \%1 arttığında \%0,13, LNET $\% 1$ arttığında ise Model 1'de \%0,40, Model 2'de \%0,41 artmıştır.

Sonuçlar birlikte değerlendirildiğinde; ekonomik büyüme; özel sektör tarafindan kullanılan kredi miktar1 \%1 arttı̆ında, FMOLS, DOLS ve CCR yöntemlerinde sırasıly $\% 0,14 ; \% 0,13$ ve $\% 0,14$ yani kısaca ortalama $\% 0,14$, geniş anlamda para arzı $\% 1$ arttı̆ında sırasıly $\% 0,14, \% 0,24$ ve $\% 0,13$ yani ortalama $\% 17$ oranında, enerji tüketimi $\% 1$ arttığında ise sirasıyla $\% 0,38 ; \% 0,40 ; \% 0,41 ; \% 0,40 ; \% 0,41$ yani ortalama \%0,40 artmıştır. Bu sonuçlara göre; Türkiye'de 1960-2019 döneminde ekonomik büyümeyi en fazla etkileyen faktör; enerji tüketimi olmuştur. Onu geniş anlamda para arzı ve özel sektör kredileri takip etmiştir. Burada para arzının daha büyük etkiye sahip olması; Türkiye'deki ekonomik büyümenin genel olarak özel sektör eliyle değil de devlet kontrolü ve yönlendirmesiyle gerçekleştiğine işaret emektedir.

\section{Kısa Dönem Analiz Bulguları}

Çalışmada kısa dönem analizleri, hata düzeltme modeli (Error Correction Model: ECM) çerçevesinde, serilerin birinci farkı alınmış halleri ve uzun dönem analizlerinden elde edilen hata düzeltme terimleri (Error Correction Term: ECT) kullanılarak, FMOLS, DOLS ve CCR yöntemleriyle gerçekleştirilmiş ve elde edilen sonuçlar Tablo 12'de sunulmuştur. 
Tablo 12. Kısa Dönem Analizi Sonucları

\begin{tabular}{|c|c|c|c|c|c|c|}
\hline \multirow{2}{*}{$\begin{array}{l}\text { Açıklayıcı } \\
\text { Değişkenler }\end{array}$} & \multicolumn{2}{|c|}{ FMOLS } & \multicolumn{2}{|c|}{ DOLS } & \multicolumn{2}{|c|}{$C C R$} \\
\hline & Model 1 & Model 2 & Model 1 & Model 2 & Model 1 & Model 2 \\
\hline$\Delta L n K R$ & $0,08^{* * *}(0,00)$ & - & $0,07 * * *(0,00)$ & - & $0,08^{* * *}(0,00)$ & - \\
\hline$\Delta L n M 2$ & - & $0,04 *(0,06)$ & - & $0,04 * * *(0,00)$ & - & $0,03(0,22)$ \\
\hline$\triangle L n E T$ & $0,54^{* * *}(0,00)$ & $0,69 * * *(0,00)$ & $0,53^{* * *}(0,00)$ & $0,68^{* * *}(0,00)$ & $0,52^{* * *}(0,00)$ & $0,71 * * *(0,00)$ \\
\hline$\Delta K_{1971}$ & - & $0,01(0,18)$ & - & $0,01 * * *(0,00)$ & - & $0,01(0,59)$ \\
\hline$\Delta K_{1976}$ & $0,02 *(0,05)$ & - & $0,02(0,12)$ & - & $0,0(0,52)$ & - \\
\hline$\Delta K_{1979}$ & $0,009(0,51)$ & $0,02(0,10)$ & $0,01(0,58)$ & $0,02^{* * *}(0,00)$ & $0,0007(0,97)$ & $0,03(0,27)$ \\
\hline$\Delta K_{1983}$ & $-0,03 * *(0,02)$ & - & $-0,03 *(0,06)$ & - & $-0,03(0,20)$ & - \\
\hline$\Delta K_{1993}$ & - & $0,03 * *(0,01)$ & - & $0,03 * * *(0,00)$ & - & $0,04^{*}(0,08)$ \\
\hline$\Delta K_{1998}$ & $0,01(0,15)$ & - & $0,02(0,18)$ & - & $0,01(0,61)$ & - \\
\hline$\Delta K_{2004}$ & - & $0,005(0,65)$ & - & $0,005(0,21)$ & - & $0,005(0,83)$ \\
\hline$\Delta K_{2009}$ & $-0,02 *(0,05)$ & - & $-0,03^{*}(0,08)$ & - & $-0,03(0,24)$ & - \\
\hline$\Delta K_{2012}$ & - & $-0,03^{* * *}(0,00)$ & - & $-0,03^{* * *}(0,00)$ & - & $-0,05^{*}(0,06)$ \\
\hline $\begin{array}{l}\text { Sabit } \\
\text { Terim }\end{array}$ & $0,003(0,25)$ & $0,002(0,43)$ & $0,004(0,30)$ & $0,003(0,27)$ & $0,003(0,39)$ & $0,002(0,48)$ \\
\hline$E C T_{t-1}$ & $-0,16^{* *}(0,02)$ & $-0,07 *(0,08)$ & $-0,22^{* *}(0,01)$ & $-0,09 * * *(0,00)$ & $-0,14^{*}(0,08)$ & $-0,08^{*}(0,09)$ \\
\hline \multicolumn{7}{|c|}{ Model Doğrulama Testleri } \\
\hline$R^{2}$ & 0,76 & 0,66 & 0,76 & 0,66 & 0,75 & 0,64 \\
\hline $\bar{R}^{2}$ & 0,72 & 0,60 & 0,72 & 0,60 & 0,70 & 0,58 \\
\hline$S E R$ & 0,02 & 0,02 & 0,02 & 0,02 & 0,02 & 0,02 \\
\hline$L R V$ & 0,0003 & 0,0003 & 0,0005 & 0,02 & 0,0003 & 0,0003 \\
\hline$S S R$ & 0,02 & 0,03 & 0,02 & 0,03 & 0,02 & 0,03 \\
\hline
\end{tabular}

Not: SER; Standart Error of Regression (Regresyonun Standart Hatas1), LRV; Lon-run Variance (Uzun Dönem Varyans1), SSR; Sum Squares Resid (Hata Terimlerinin Kareleri Toplamı)'dır. *, ** ve ***; katsayıların sırasıyla \%10, \%5 ve \%1 düzeyinde istatistiksel olarak anlamlı olduklarını göstermektedir.

Tablo 12'de yer alan sonuçlara göre; FMOLS yöntemiyle yapılan tahminde; kredi hacmindeki ve para arzındaki artışların ekonomik büyümeyi kısa dönemde de artırdıkları (katsayılar 0,08; 0,04), enerji tüketiminin ekonomik büyüme üzerindeki etkisinin Model 1'de 0,54, Model 2'de 0,69 olduğu görülmektedir. Bu yöntemde hata düzeltme terimlerinin katsayıları sırasıyla $-0,16$ ve $-0,07$ çıkmış olup, bu sonuçlar, modellerin hata düzeltme mekanizmalarının çalışı̆̆ını ifade etmektedir. DOLS yöntemiyle yapılan tahminde; kredi hacmindeki ve para arzındaki artısların ekonomik büyümeyi kısa dönemde de artırdıkları (katsayılar 0,07; 0,04), enerji tüketiminin ekonomik büyüme üzerindeki etkisinin Model 1'de 0,53 , Model 2'de 0,68 olduğu görülmektedir. Bu yöntemde hata düzeltme terimlerinin katsayıları sirasılyla $-0,22$ ve $-0,09$ çıkmış olup, bu sonuçlar, modellerin hata düzeltme mekanizmalarının çalıştığını ifade etmektedir. CCR yöntemiyle yapılan tahminde; kredi hacmindeki ve para arzındaki artışların ekonomik büyümeyi kısa dönemde de artırdıkları (katsayılar 0,08; 0,03), enerji tüketiminin ekonomik büyüme üzerindeki etkisinin Model 1'de 0,52, Model 2'de 0,71 olduğu görülmektedir. Bu yöntemde hata düzeltme terimlerinin katsayıları sırasıyla $-0,14$ ve $-0,08$ çıkmıs olup, bu sonuçlar, modellerin hata düzeltme mekanizmalarının çalıştı̆ııı ifade etmektedir.

Uzun ve kısa dönem analizlkerinde elde edilen sonuçlar genel olarak değerlendirildiğinde; özel sektör tarafindan kullanılan krediler ekonomik büyümeyi kısa dönemde de artırmaktadır (çünkü KR'nin katsayısı FMOLS, DOLS ve CCR yöntemlerine göre sirasiyla 0,$08 ; 0,07$ ve 0,08 'dir), ancak bu etki uzun dönemdekinden çok daha küçüktür (çünkü uzun dönemde ortalama 0,14 idi). Geniş anlamda para arzındaki artısların da ekonomik büyüme üzerindeki kısa dönemli etkileri pozitif (sırasıyla 0,04; 0,03; 0,04 ) ve uzun dönemdekinden daha küçüktür (çünkü uzun dönemde ortalama 0,17 idi). Enerji tüketiminin ise ekonomik büyümeyi kısa dönemde, uzun dönemdekinden çok daha fazla etkilediği görülmektedir. Çünkü kısa dönem katsayıları FMOLS, DOLS ve CCR yöntemlerine göre sırasıyla 0,54; 0,$69 ; 0,53 ; 0,68 ; 0,52 ; 0,71$ iken uzun dönemde ortalama 0,40 idi. Hata düzeltme terimlerinin katsaylları, beklendiği gibi negatif ve istatistiksel olarak anlamlı bulunmuştur. Bu durumda; modellerin hata düzeltme mekanizmaları çalışmaktadır ve yapılan analizler güvenilirdir.

\section{Nedensellik Testi Bulguları}

Bu çalışmada kullanılan seriler birinci farklarında durağan ve aralarında eşbütünleşme ilişkisi de tespit edildiği için aralarındaki nedensellik ilişkilerinin VECM'ye dayalı Granger nedensellik testi ile incelenmesi gerekmektedir. Bu amaçla çalışmada kullanılan denklemlerin bu çalışmaya uyarlanmış halleri: 


$$
\begin{aligned}
& \Delta L n E B_{t}=\alpha_{0}+\alpha_{1} E C T_{t-1}+\sum_{i=1}^{p} \alpha_{2 i} \Delta L n E B_{t-i}+\sum_{i=1}^{p} \alpha_{3 i} \Delta L n K R_{t-i}+\sum_{i=1}^{p} \alpha_{4 i} \Delta L n E T_{t-i}+\sum_{i=1}^{p} \alpha_{5 i} \Delta L n M 2_{t-i}+u_{t} \\
& \Delta L n K R_{t}=\beta_{0}+\beta_{1} E C T_{t-1}+\sum_{i=1}^{p} \beta_{2 i} \Delta L n K R_{t-i}+\sum_{i=1}^{p} \beta_{3 i} \Delta L n E B_{t-i}+\sum_{i=1}^{p} \beta_{4 i} \Delta L n E T_{t-i}+\sum_{i=1}^{p} \beta_{5 i} \Delta L n M 2_{t-i}+v_{t} \\
& \Delta L n E T_{t}=\gamma_{0}+\gamma_{1} E C T_{t-1}+\sum_{i=1}^{p} \gamma_{2 i} \Delta L n E T_{t-i}+\sum_{i=1}^{p} \gamma_{3 i} \Delta L n K R_{t-i}+\sum_{i=1}^{p} \gamma_{4 i} \Delta L n E B_{t-i}+\sum_{i=1}^{p} \gamma_{5 i} \Delta L n M 2_{t-i}+\vartheta_{t} \\
& \Delta L n M 2_{t}=\theta_{0}+\theta_{1} E C T_{t-1}+\sum_{i=1}^{p} \theta_{2 i} \Delta L n M 2_{t-i}+\sum_{i=1}^{p} \theta_{3 i} \Delta L n K R_{t-i}+\sum_{i=1}^{p} \theta_{4 i} \Delta L n E T_{t-i}+\sum_{i=1} \theta_{5 i} \Delta L n E B_{t-i}+\omega_{t}
\end{aligned}
$$

şeklindedir. Bu denklemlerde $\alpha_{1}, \beta_{1}, \gamma_{1}$ ve $\theta_{1}$; uzun dönem nedensellik ilişkilerinin varlığını sınayan katsayılardır. $\triangle \operatorname{LnEB}, \Delta \operatorname{LnKR}, \Delta \operatorname{LnET}$ ve $\Delta L n M 2$; kısa dönem nedensellik ilişkilerinin varlı̆̆ını test etmede kullanılan, birinci dereceden farkı alınarak durağanlaştırılmış değişkenlerdir. $\Delta$; birinci dereceden fark operatörünü, $t$; zamanı, $p$ optimal gecikme uzunluğunu, $u_{t}, v_{t}, \vartheta_{t}$ ve $\omega_{t}$; ekonometrik olarak

\begin{tabular}{|c|c|c|c|c|c|}
\hline \multirow{3}{*}{$\begin{array}{l}\text { Bağımlı } \\
\text { Değıisken }\end{array}$} & \multicolumn{5}{|c|}{ Bağımsız Değişken } \\
\hline & \multicolumn{4}{|c|}{ Kısa Dönem Nedensellik } & Uzun Dönem Nedensellik \\
\hline & $\triangle \operatorname{LnEB}$ & $\Delta \operatorname{LnKR}$ & $\triangle$ LnET & $\Delta \operatorname{LnM2}$ & $E C T_{t-1}$ \\
\hline$\overline{\Delta L n E B}$ & - & $0,005(0,93)$ & $0,77(0,37)$ & $0,21(0,64)$ & $0,18[1,13]$ \\
\hline$\Delta \operatorname{LnKR}$ & $1,58(0,20)$ & - & $2,01(0,15)$ & $0,97(0,32)$ & $-0,39[-0,49]$ \\
\hline$\triangle L n E T$ & $0,01(0,90)$ & $3,35 *(0,06)$ & - & $5,63 * *(0,01)$ & $0,69 * * *[4,78]$ \\
\hline$\Delta \operatorname{LnM} 2$ & $0,71(0,39)$ & $0,16(0,68)$ & $5,19 * *(0,02)$ & - & $-1,59 * * *[-3,18]$ \\
\hline
\end{tabular}
sorunsuz hata terimleri serilerini göstermektedir. Bu çalışmada VECM'ye dayalı nedensellik testi yapılmış ve elde edilen bulgular Tablo 13'te sunulmuştur.

Tablo 13. VECM'ye Dayal Nedensellik Testi Sonuçar kritik değerler (tablo değerleri) sırasılyla 1,64; 1,96 ve 2,57 'dir. $*$, ** ve $* * *$ sırastyla $\% 10, \% 5$ ve $\% 1$ anlamllık düzeyinde nedensellik ilişkisinin varlığını ifade etmektedir. Normal parantez içindekiler, olasılık değerleridir.

Tablo 13'teki sonuçlara göre; ilk satırda yer alan $E C T_{t-1}$ 'e ait katsayının $t$ istatistiği $(1,13), \% 10$ anlamllık düzeyine sahip kritik $t$ istatistiği değeri olan 1,64'ten büyük olmadığı için Türkiye'de 1960-2019 döneminde kredi hacmi, enerji tüketimi ve para arzından ekonomik büyümeye doğru bir uzun dönemli nedensellik ilişkisinin olmadığı görülmektedir. Burada özellikle krediler ve para arzı ile ekonomik büyüme arasındaki ilişkiler, Klasik Dikotomi varsayımının Türkiye açısından uzun dönemde geçerli olduğunu ima etmektedir. Benzer şekilde ikinci satırda yer alan $E C T_{t-1}$ 'e ait katsayının $t$ istatistiği $(-0,49), \% 10$ anlamllık düzeyine sahip kritik $t$ istatistiği değeri olan 1,64'ten mutlak değerce büyük olmadığı için ekonomik büyüme, enerji tüketimi ve para arzından kredi hacmine doğru da bir uzun dönemli nedensellik ilişkisi belirlenememiştir. Bağımlı değişkenin $\Delta$ LnET olduğu modelde (Tablodaki 3. satırda); ekonomik büyüme, kredi hacmi ve para arzından enerji tüketimine doğru tek yönlü uzun dönemli bir nedensellik ilişkisinin var olduğu görülmektedir. Çünkü bu satırda yer alan $E C T_{t-1}$ 'e ait katsayının $t$ istatistiği $(4,78)$, $\% 1$ anlamlılık düzeyine sahip kritik $t$ istatistiği değeri olan 2,57'den büyüktür. Bağımlı değişkenin $\Delta L n M 2$ olduğu modelde ise; ekonomik büyüme, kredi hacmi ve enerji tüketiminden para arzına doğru tek yönlü uzun dönemli bir nedensellik ilişkisinin var olduğu belirlenmiştir. Çünkü Tablodaki dördüncü satırda yer alan $E C T_{t-1}$ 'e ait katsayının $t$ istatistiği $(-3,18), \% 1$ anlamlllk düzeyine sahip kritik $t$ istatistiği değeri olan 2,57'den mutlak değerce büyüktür.

\section{Sonuç ve Değerlendirme}

Bu çalışmada; finansal gelişme ve enerji tüketiminin ekonomik büyüme üzerindeki etkileri, 1960-2019 dönemi yıllık verileri kullanılarak analiz edilmiştir. Serilerin durağanlı̆̆1, Vogelsang ve Perron (1998), Lee ve Strazicich (2003) ve Carrion-i-Silvestre vd. (2009) yapısal kır1lmalı birim kök testleri kullanılarak analiz edilmiş ve tüm serilerin I(1) olduklarına karar verilmiştir. Modellerde yer alan seriler arasında eşbütünleşme ilişkisinin varllğı; Gregory ve Hansen (1996) ve Maki (2012) yapısal kırılmalı eşbütünleşme testleriyle incelenmiş ve modellerde yer alan değişkenler arasında eşbütünleşme ilişkisi var olduğu belirlenmiştir. Yani bu seriler birlikte hareket etmektedirler ve bu serilerin düzey değerleri kullanılarak yapılacak analizlerde 
sahte regresyon sorunu ile karşılaşılmayacaktır. Maki (2012) çoklu yapısal kırılmalı eşbütünleşme testinde belirlenen yapısal kırılma tarihleri, uzun ve kısa dönem analizlerine kukla değişkenlerde dâhil edilmiştir.

Uzun dönem analizleri; FMOLS, DOLS ve CCR yöntemleriyle gerçekleştirilmiştir. Bu analizler sonucunda; ekonomik büyümenin, özel sektör tarafindan kullanılan kredi miktarı \%1 arttığında ortalama $\% 0,13$, para arz1 $\% 1$ arttığında $\% 0,13$ ile $\% 0,24$ arasında, enerji tüketimi $\% 1$ arttığında ise ortalama \%0,40 civarında arttığı belirlenmiştir. Bu sonuçlara göre; Türkiye'de 1960-2019 döneminde ekonomik büyümeyi en fazla etkileyen faktör; enerji tüketimi olmuştur. Onu para arzı ve özel sektör kredileri takip etmiştir. Bu çalş̧madan elde edilen bulgular literatürde yer alan; Özata (2010); Dumrul (2011); Shahbaz, Abosedra ve Sbia (2013); SSentürk (2012); Hayaloğlu (2015); Doğan ve Değer (2016); Lu (2017); Sağlam ve Erataş Sönmez (2017); Mukhtarov vd. (2018); Uslu (2018); Bist (2018) ve Aydın (2019) çalışmalarının bulgularıla tutarlidır.

Çalışmada kısa dönem analizleri, hata düzeltme modeli çerçevesinde, yine FMOLS, DOLS ve CCR yöntemleriyle gerçekleştirilmiştir. Bu analizler sonucunda; kredilerin ekonomik büyümeyi kısa dönemde de artırdığı, ancak bu etkinin uzun dönemdekinden daha küçük olduğu belirlenmiştir. Para arzındaki artşsların da ekonomik büyüme üzerindeki kısa dönemli etkilerinin pozitif ve uzun dönemdekinden daha küçük olduğu görülmüştür. Enerji tüketiminin ise ekonomik büyümeyi kısa dönemde, uzun dönemdekinden daha fazla etkilediği tespit edilmiştir. Modellere ait hata düzeltme terimlerinin katsaylları, negatif ve istatistiksel olarak anlamlı bulunmuş, bu sonuca dayanarak, modellerin hata düzeltme mekanizmalarının çalıstığına ve yapılan analizlerin güvenilir olduğuna karar verilmiştir.

Çalışmada uzun ve kısa dönem analizlerinin FMOLS, DOLS ve CCR yöntemlerinin üçü de kullanılarak gerçekleştirilmiş olması, bütün detayların göz önünde bulundurulmasına olanak sağlayarak, çalışmayı daha güçlü hale getirmiştir. Çünkü bir yöntem ile belirlenemeyen bir etkinin diğer yöntem kullanılarak ortaya çıkarılması mümkün olmuştur.

Çalışmada kullanılan seriler birinci farkta durağan oldukları ve aralarında eşbütünleşme ilişkisi de tespit edildiği için aralarındaki nedensellik ilişkileri VECM yöntemiyle analiz edilmiştir. Buna göre; Türkiye'de 1960-2019 döneminde ekonomik büyümeden enerji tüketimi ve para arzına doğru tek yönlü, kredi hacminden enerji tüketimi ve para arzına doğru tek yönlü, enerji tüketimi ile para arzı arasında iki yönlü uzun dönem nedensellik ilişkilerinin var olduğu bulunmuştur. Öte yandan Türkiye'de 1960-2019 döneminde kredi hacminden enerji tüketimine doğru tek yönlü, enerji tüketimi ile para arazı arasında iki yönlü kısa dönem nedensellik ilişkilerinin var olduğu tespit edilmiştir. Bu analizden elde edilen bulgular literatürde yer alan; Aytaç (2010); Ndlovu (2013); Rezitis ve Ahammad (2015); Magazzino (2016) ve Akhtar, Sheikh ve Altaf (2016) çalışmalarının bulgularıly uyumludur.

Bu çalışmadan elde edilen bulgulara dayanarak; özel sektöre verilen kredilerin, parasal genişlemenin ve enerji tüketiminin ekonomik büyümeyi artırdığı, özel sektöre verilen krediler ve parasal genişlemenin uzun dönemli, enerji tüketiminin kısa dönemli etkilerinin daha büyük olduğu söylenebilir. Bu nedenle politika yapıcıların ülkedeki ekonomik büyümeyi istikrarlı bir şekilde artırabilmek için; bir yandan parasal genişlemeye önem vererek, özel sektörün kredilere erişimini kolaylaştırmasının, diğer yandan da ülkedeki enerji üretim ve iletimini geliştirerek, hanehalkı ve firmaların ucuz ve güvenli biçimde enerjiye erişimlerini sağlamaya çalışmalarının yararlı olacağı değerlendirilmektedir. Ancak; parasal genişlemenin, Friedman'ın da ifade ettiği gibi enflasyona neden olabileceği unutulmamalı, bu politikaya belki ekonomik daralma dönemlerinde ve kısa süreli olarak başvurulmalıdır. Diğer yandan, özel sektörün kredi kullanımı kolaylaştırllırken, finans sistemini zor duruma düşürebilecek riskli işlemlerden uzak durulmalı, bu konuda 2012 y1lindan itibaren uygulanmakta olan makro ihtiyati politikalardan taviz verilmemelidir.

\section{Etik Beyan}

“Türkiye'de Finansal Gelisme ve Enerji Tüketiminin Ekonomik Büyüme Üzerindeki Etkisi: Yapısal Korlmah Bir Analiz”" başlıklı çalışmanın yazım sürecinde bilimsel kurallara, etik ve alıntı kurallarına uyulmuş; toplanan veriler üzerinde herhangi bir tahrifat yapılmamış ve bu çalışma herhangi başka bir akademik yayın ortamına değerlendirme için gönderilmemiştir. Bu araştırmada hazır veri seti kullanıldığ1 için etik kurul kararı zorunluluğu taşımamaktadır. 


\section{Kaynakça}

Akhtar, M. H., Sheikh, M. R. ve Altaf, A. (2016). Financial development, energy consumption and trade openness nexus: Empirical evidence from selected south Asian countries. Pakistan Journal of Social Sciences (PJSS), 36(1), 505-518.

Akkaya, H. (2016). Kamu harcamalarmın ekonomik büyüme üzerine etkisi, gelișmis ve gelişmekte olan ülke karşılaștırması (Yüksek Lisans Tezi). Nevşehir Hacı Bektaş Veli Üniversitesi, Sosyal Bilimler Enstitüsü, İktisat Anabilim Dalı, Nevşehir.

Albayrak, K. (2019). Türkiye'nin enerji ekonomisi ve cari açı için yenilenebilir enerji keaynakelarmmn önemi (Yüksek Lisans Tezi). KTO Karatay Üniversitesi, Sosyal Bilimler Enstitüsü, İşletme Anabilim Dalı, Konya.

Allard, A., Takman, J., Uddin, G. S. ve Ahmed, A. (2018). The n-shaped environmental Kuznets curve: An empirical evaluation using a panel quantile regression approach. Environmental Science and Pollution Research, 25, 5848-5861.

Anton, S. G. ve Nucu, A. E. A. (2020). The effect of financial development on renewable energy consumption. A Panel Data Approach. Renewable Energy, 147, 330-338.

Arslan, Ü. Ç. ve Demirağ, Y. H. (2017). Sanayi devrimi: Sonuclar ve uluslararası sisteme yansımalar (Yüksek Lisans Tezi). Başkent Üniversitesi, Avrupa Birliği ve Uluslararası İlișkiler Enstitüsü, Ankara.

Atamtürk, B. (2007). Gelişmekte olan ülkelerde ve türkiye'de finansal serbestleşmenin iç tasarruflar üzerine etkisi. Marmara Üniversitesi İ.̇.B.F. Dergisi, 23(2), 75-89.

Avcı, G. M. (2018). İhracata Dayalı Büyümede Kurumlarn Rolü: Dinamik Panel Veri Analizi (Doktora Tezi). Zonguldak Bülent Ecevit Üniversitesi, Sosyal Bilimler Enstitüsü, İktisat Anabilim Dalı, Zonguldak.

Aydın, M. K. (2003). Kapitalizm ve kriz. Kocaeli Üniversitesi Sosyal Bilimler Enstitüsü Dergisi, 6(2), 1-10.

Aydın, F. F. (2010). Enerji tüketimi ve ekonomik büyüme. Erciyes Üniversitesi İktisadi ve İdari Bilimler Fakültesi Dergisi, $35,317-340$.

Aydın, Y. (2019). Finansal gelişme ve ekonomik büyüme ilişkisinin kırılgan beşli ülkeleri için analizi. Ekonomi, Politika ve Finans Arastirmalar Dergisi, 4(1), 37-49.

Aytaç, D. (2010). Enerji ve ekonomik büyüme ilişkisinin çok değişkenli VAR yaklaşımı ile tahmini. Maliye Dergisi, 158(1), 482-495.

Aytun, C. (2014). Çevresel Kuznets eğrisi hipotezi: Panel veri analizi. Akademik Bakıs Dergisi, 44, 1-15.

Beckerman, W. (1992). Economic growth and the environment: Whose growth? Whose environment? World Development, 20(4), 481-496.

Berk, E. (2014). Türkiye'de para talebi: Basit ve divisia ölçümlerle ampirik bir analiž (Yüksek Lisans Tezi). Pamukkale Üniversitesi, Sosyal Bilimler Enstitüsü, İktisat Anabilim Dalı, Denizli.

Bilen, İ.E. (2010). Araştrrma-geliștirme (Ar-Ge) ve ekonomik büyüme: Seçilmiş gelismekte olan ülkeler üzerine bir uygulama (Yüksek Lisans Tezi). Atatürk Üniversitesi, Sosyal Bilimler Enstitüsü, İktisat Anabilim Dalı, Erzurum.

Bist, J. P. ve Read, R. (2018). Financial development and economic growth: Evidence from a panel of 16 African and non-African low-income countries. Cogent Economics ve Finance, 6(1), 1-17.

Bozoklu, Ş. ve Yılancı, V. (2013). Finansal gelişme ve iktisadi büyüme arasındaki nedensellik ilişkisi: Gelişmekte olan ekonomiler için analiz. Dokuz. Eylül Üniversitesi İktisadi ve İdari Bilimler Fakültesi Dergisi, 28(2), 161-187.

Carrion-i-Silvestre, J. L., Kim, D. ve Perron, P. (2009). GLS-based unit root tests with multiple structural breaks under both the null and the alternative hypotheses. Econometric Theory, 25, 1754-1792.

Cihan, E. (2019). Yenilenebilir enerji ve Türkiye'de günes enerjisi (Yüksek Lisans Tezi). Hasan Kalyoncu Üniversitesi, Sosyal Bilimler Enstitüsü, İktisat Anabilim Dalı, Gaziantep.

Contürk, F. Y. ve Güngör, B. (2016). Asimetrik nedensellik testi ile finansal gelişme ekonomik büyüme ilişkisinin analizi. Muhasebe ve Finansman Dergisi, Temmuz, 89-108.

Çapın, C. ve Söylem, A. (2017). Dağıtık tesisli işletmelerde enerji tüketimi į̧leme ve raporlama sistemleri. Erişim adresi: http://www.emo.org.tr/ekler/703482da33d81a6_ek.pdf, Erişim tarihi: 02.12.2019.

Çelebi Boz, F., Çınar, Ö. ve Temelli, F. (2017). The relationship between energy consumption, financial development and economic growth: An analysis on the ASEAN countries. BJSS Balkan Journal of Social Sciences, 6(12), 36-52.

Dam, M. M., Karakaya, E. ve Bulut, Ş. (2013). Çevresel Kuznets eğrisi ve Türkiye: Ampirik bir analiz. Dumlupınar Üniversitesi Sosyal Bilimler Dergisi, EYI 2013 Özel Sayısı, 85-96.

Demir, O. ve Üzümcü, A. (2003). İçsel büyümenin kaynaklar1. Atatürk Üniversitesi İ.I.B.F. Dergisi, 17(3-4), 17-37.

Doğan, B. ve Değer, O. (2016). Enerji tüketimi, finansal gelişme ve ekonomik büyüme ilişkisi: Hindistan örneklemi. Journal of Yasar University, 11(44), 326-338.

Doğanay, H. ve Coşkun, O. (2017). Enerji kaynaklar (Güncellenmiş 3. Baskı). Ankara: Pegem Akademi.

Domar, J. D. (1946). Capital expansion, rate of growth and employment. Econometrica, 137-147.

Domar, E. D. (1947). Expansion, and employment, the American review. Econometrica, 37(1), 33-55.

Dumrul, Y. (2011). Enerji tüketimi ve ekonomik büyüme iliskisi: Teori ve Türkiye uygulaması (Doktora Tezi). Erciyes Üniversitesi, Sosyal Bilimler Enstitüsü, İktisat Anabilim Dalı, Kayseri.

Durusu Çiftçi, D. (2015). Finansal gelişme ve ekonomik büyüme ilişkisi: Bir genişletilmiş Solow büyüme modeli denemesi ve ampirik uygulama (Doktora Tezi). Pamukkale Üniversitesi, Sosyal Bilimler Enstitüsü, Denizli.

Engin Balın, B. ve Mumcu Akan, H. D. (2015). EKC hypothesis and the effect of innovation: A panel data analysis. Journal of Business, Economics \& Finance, 4(1), 81-91.

Engle, R. F. ve Granger, C. W. J. (1987). Cointegration and error-correction: Representation, estimation and testing. Econometrica, 66, 251-276. 
Er, S. (2011), Finansal krizleri önleme aracı olarak finansal sektörün regülasyonu, Mortgage krizi ve Türkiye. Maliye Dergisi, 160, 307-327.

Erataş Sönmez, F. ve Sağlam, Y. (2019). Gelişmekte olan ülkeler için finansal gelişim ile ekonomik büyüme arasındaki ilișki: Panel nedensellik analizi. Sosyoekonomi, 27(42), 87-106.

Erdem, E. ve Dumrul, C. (2014). Keynesyen ve neo-klasik yaklaşımlarda finansal sistem ve iktisadî büyüme. Uludă̆ Üniversitesi İktisadi ve İdari Bilimler Fakültesi Dergisi, XXXIII (2), 45-86.

Erdoğan, S. ve Gürbüz, S. (2014). Türkiye'de enerji tüketimi ve ekonomik büyüme ilişkisi: yapısal kırılmalı zaman serisi analizi. Selçk Üniversitesi Sosyal Bilimler Enstitüsü Dergisi, 32, 79-87.

Esteve, V. ve Requena, F. (2006). A cointegration analysis of car advertising and sales data in the presence of structural change. International Journal of the Economics of Business, 13(1), 111-128.

EVDS (2019a). GSYIH - Harcama Yöntemiyle-Cari Fiyatlarla (TÜIK) (Bin TL) (Üc Aylık). Erişim adresi: https://evds2.tcmb.gov.tr/index.php?/evds/serieMarket, Erişim Tarihi: 22.06.2019.

EVDS (2019b). Kurlar-Döviz Kurlar $\left(^{*}\right) \quad$ (Günlüke). Erişim https://evds2.tcmb.gov.tr/index.php?/evds/serieMarket, Erişim tarihi: 15.10.2019.

Eviews 10 User Guide II (2010). Eviews 10 User's Guide. Erişim adresi: https://www3.nd.edu/ nmark/FinancialEconometrics/EViews10_Manuals/EViews\%2010\%20Users\%20Gui de\%20II.pdf, Erişim Tarihi: 14.02.2020.

Finansalgoz (2017). Finansal sistem nedir? Erişim adresi: https://www.finansalgoz.com/2017 /02/finansal-sistemnedir.html, Erişim Tarihi: 12.09.2019.

Furstenberg, V. G. M. ve Fratianni, M. (1996). Indicators of financial development. North American Journal of Economics and Finance, 7(1), 19-29.

Gomez, M. ve Rodriguez, J. C. (2019). Energy consumption and financial development in NAFTA countries, 19712015. Applied Sciences, 9, 1-11.

Gregory, A. W. ve Hansen, B. E. (1996). Residual-based tests for cointegration in models with regime shifts. Journal of Econometrics, 70(1), 99-126.

Grossman, G. ve Krueger, A. (1995). Economic growth and the environment. Quarterly Journal of Economics, (May), 353-77.

Gujarati, D. N. ve Porter, D. C. (2012). Temel ekonometri (5. Basımdan Çeviri) (Çev: Ü. Şenesen ve G. Günlük Şenesen). İstanbul: Literatür Yayınları.

Guo, W. W. (2018). An analysis of energy consumption and economic growth of cobb-douglas production function based on ECM. IOP Conf. Series: Earth and Environmental Science, 113, 1-6.

Gülay, A. (2008). Yenilenebilir enerji kaynaklar açısından Türkiye'nin geleceŭgi ve Avrupa Birliği ile karşılaştırlması (Yüksek Lisans Tezi) Dokuz Eylül Üniversitesi, Sosyal Bilimler Enstitüsü, İzmir.

Gültekin, H. (2015). Türkiye'de enerji ithalat giderlerinin ekonomik büyümeye etkisi (Yüksek Lisans Tezi) Trakya Üniversitesi Sosyal Bilimler Enstitüsü, Edirne.

Güvel, E. A. (2011). Ekonomik büyüme kuramlar. Uluslarn zenginliklerinin dinamikleri. Adana: Karahan Kitabevi.

Harris, D. J. (2007). The Classical Theory of Economic Growth. Erişim adresi: https://web.stanford.edu/ dharris/papers/The \%20Classical $\% 20$ Theory $\% 20$ of $\% 20$ Economic $\% 20$ Growth $\% 2$ 0\%5Bpre-print \%5D.pdf, Erişim Tarihi: 18.09.2019.

Harrod, R. F. (1937). Mr. Keynes and traditional theory. Econometrica, 5(1), 74-86.

Harrod R. F. (1939). An essay in dynamic theory. The Economic Journal, 49(193), 14-33.

Hayaloğlu, P. (2015). Kurılgan beşli ülkelerinde finansal gelişme ve ekonomik büyüme ilişkisi: Dinamik panel veri analizi. Ekonomik ve Sosyal Araşttrmalar Dergisi, 11(1), 131-144.

Janicke, M., Binder, M. ve Mönch, H. (1997). Dirty industries: Patterns of change in industrial countries. Environmental and Resource Economics, 9, 467-491.

Jones, C. I. (2001). İktisadi büyümeye giriş (Çev: S. Ateş ve İ. Tuncer). Istanbul: Literatür Yayınları.

Kao, C. W. ve Wan, J. Y. (2017). Energy consumption and economic growth: Further evidence from Taiwan. International Journal of Economics and Finance, 9(7), 165-178.

Kasperowicz, R. (2014). Electricity consumption and economic growth: Evidence from Poland. Journal of International Studies, 7(1), 46-57.

Karakoç, H., Erbay, B. ve Aras, H. (2011). Enerji analiz̧i. Eskişehir: Anadolu Üniversitesi Açı̈öğretim Fakültesi Yayın1, No: 1457.

Kılıç, C. (2012). Finansal liberalizasyon sürecinde Türkiye'nin sektörel yapisinda meydana gelen değişmeler. Kafkeas Üniversitesi, İktisadi ve İdari Bilimler Fakültesi Dergisi, 3(4), 107-148.

Kızılkaya, O. (2017). Bölüm 4. çă̆daş büyüme modelleri, Erişim adresi: https://akademik.ahievran. edu.tr/site/oktaykizilkaya/22088, Erişim Tarihi: 18.09.2019.

Kitov, I. (2006). Real GDP Per Capita in Developed Countries. MPRA Paper No. 14450.

Koç, İ. C. (2000). İzmir iktisat kongresi'nin Türk ekonomisinin oluşumuna etkileri. Atatürk Dergisi, 3(1), 145-167.

Koçak, E. (2014). Türkiye'de çevresel Kuznets eğrisi hipotezinin geçerliliği: ARDL sinir testi yaklaşimi. Issletme ve İktisat Calısmalar Dergisi, 2(3), 62-73.

Korkut, T. (2018). Kyoto protokolü nedir? Erişim adresi: http://bianet.org/bianet/cevre-ekoloji/54452-kyotoprotokolu-nedir-ne-degildir, Erişim Tarihi: 26.09.2019. 
Kuznets, S. (1955). Economic growth and income inequality. American Economic Review, 45(1), 1-28.

Lebe, F. (2016). Çevresel kuznets eğrisi hipotezi: Türkiye için eşbütünleşme ve nedensellik analizi. Doğus Üniversitesi Dergisi, 17(2), 177-194.

Lee, J. ve Strazicich, M. C. (2003). Minimum lagrange multiplier unit root test with two structural breaks. The Review of Economics and Statistics, 85(4), 1082-1089.

Lloyd, P. J. (2017). The role of energy in development. Journal of Energy in Southern Africa, 28(1), 54-62.

Lucas, R. E. (1988). On the mechanics of economic development. Journal of Monetary Economics, 22, 3-42.

Magazzino, C. (2016). Energy consumption, real GDP, and financial development nexus in Italy: an application of an auto-regressive distributed lag bound testing approach. This paper is part of the Proceedings of the 2nd International Conference on Energy Production and Management (EQ 2016).

Maki, D. (2012). Tests for cointegration allowing for an unknown number of breaks. Economic Modelling, 29(5), 2011 2015.

Malik, M. N. A. ve Masih, M. (2017). The relationship between energy consumption, financial development and economic growth: An evidence from Malaysia based on ARDL. Munich Personal RePEc Archive, MPRA Paper No. 86374.

Mammadov, E. (2016). Finansal gelişme ve ekonomik büyüme: Ažrbaycan örneği. (Doktora Tezi) Marmara Üniversitesi, Bankacilık ve Sigortacılık Enstitüsü, İstanbul.

Mankiw, N. G. (2010). Makroekonomi (Çev. Edt: Ö. Faruk Çolak). Ankara: Efil Yayınevi.

Mattesini, F. (1996). Interest rate spreads and endogenous growth. Economic Notes, 25(1), 111-129.

McKinnon, R. (1973). Money and capital in economic development. Brookings Institution, Washington DC.

Mert, M. ve Bozdağ, H. (2013). Environmental Kuznets curve for carbon emissions in Bosnia \& Herzegovina. Dumlupinar Üniversitesi Sosyal Bilimler Dergisi EYI 2013 Özel Sayısı, 79-84.

Merton, R. C. ve Bodie, Z. (1995). A conceptual framework for analyzing the financial environment. Boston: Harvard Business School Press.

Mukhtarov, S., Mikayilov, J. I., Mammadov, J. ve Mammadov, E. (2018). The impact of financial development on energy consumption: Evidence from an oil-rich economy. Energies, 11, 1-14.

Munyanyi, M. E. (2017). Finansal gelişime ve iktisadi büyüme ilişkisi: Zimbabwe örneği (Yüksek Lisans Tezi). İstanbul Medeniyet Üniversitesi, Sosyal Bilimler Enstitüsü, İstanbul.

Narayan, P. K. (2007). Are nominal exchange rates and pricelevels co-integrated? New evidence from threshold autoregressive and momentum-threshold autoregressive models. The Economic Record, 83(260), 74-85.

Ndlovu, G. (2013). Financial sector development and economic growth: EVIDENCE from Zimbabwe. International Journal of Economics and Financial Issues, 3(2), 435-446.

Need (2018a). Natural Gas. Erişim adresi: https://www.need.org/Files/curriculum /infobook/NGasS.pdf, Erişim Tarihi: 15.09.2019.

Need (2018b). Energy Consumption. Erişim adresi: https://www.need.org/Files/curriculum/ infobook/ConsI.pdf, Erișim Tarihi: 02.12.2019.

Oğuz, O. ve Canan, A. (2016). Türkiye'de finansal sistem ve bankacılık (Edt: N. Eroglu, H. İ. Aydın, C. Y. Kesbiç). Ankara: Orion Yayınevi.

Özata, E. (2010). Türkiye'de enerji tüketimi ve ekonomik büyüme arasındaki ilişkilerin ekonometrik incelemesi. Dumlupinar Üniversitesi Sosyal Bilimler Dergisi, 26, 1-14.

Özcan, B. ve Arı, A. (2011). Finansal gelişme ve ekonomik büyüme arasındaki ilişkinin ampirik bir analizi: Türkiye örneği. Business and Economics Research Journal, 2(1), 121-142.

Özcan, S. K. (2013). Finansal Gelişme ve ve Iktisadi Büyüme Arasindaki Iliş̧kisi: Türkiye Örneği (Yüksek Lisans Tezi). Hacettepe Üniversitesi, Sosyal Bilimler Enstitüsü, Ankara.

Özkoç, H. H., Yıldırım, A. ve Kudubeş, E. (2017). Çevresel Kuznets eğrisinin geçerliliğinin düşük ve üst orta gelirli ülkeler için sınanması: 1964-2009 dönemi. Mebmet Akif Ersoy Üniversitesi Sosyal Bilimler Enstitüsü Dergisi, 9(22), 327-340.

Park, J. Y. (1992). Canonical cointegrating Regressions. Econometrica, 60, 119-143.

Peker, H. S. (2015). Avrupa'da merkantilist uygulamalar ve osmanlı ekonomisi ile bir karşılaştırma. Çankırm Karatekin Üniversitesi IIBBF Dergisi, 5(1), 1-12.

Perron, P. (2017). Unit roots and structural breaks. Econometrics, 5(22), 1-3.

Peterson, E. W. (2017). The role of population in economic growth. SAGE Open, 1-15.

Phillips, P. C. ve Hansen, B. E. (1990). Statistical inference in instrumental variables regression with I(1) processes. Te Reviewof Economic Studies, 57(1), 99-125.

Rahmani, A. (2019). Türkiye ekonomisinde yenilenebilir enerji tüketimi ve ekonomik büyüme iliskisi: Bir zaman serisi analizi (Yüksek Lisans Tezi). Tekirdağ Namık Kemal Üniversitesi, Sosyal Bilimler Enstitüsü, Tekirdağ.

Rezitis, A. N. ve Ahammad, S. M. (2015). The relationship between energy consumption and economic growth in south and southeast Asian countries: A panel vector auto regression approach and causality analysis. International Journal of Energy Economics and Policy, 5(3), 704-715.

Robinson, J. (1952). The rate of interest and other essays. London: Macmillan.

Romer, P. M. (1986). Increasing returns and long run growth. Journal of Political Economy, 94, 1002-1037.

Romer, P. M. (1990). Endogenous technological change. The Journal of Political Economy, The Problem of Development: A Conference of The Institute For Free Enterprise System, Oct. 
Saatçioğlu, C. ve Küçükaksoy, İ. (2004). Türkiye ekonomisinin enerji yoğunluğu ve önemli enerji taşıma projelerinin ekonomiye etkisi. Dumlupınar Üniversitesi Sosyal Bilimler Dergisi, 11, 19-41.

Sağlam, Y. ve Erataş Sönmez, F. (2017). Finansal gelişme ve ekonomik büyüme arasındaki ilişki: Avrupa geçiş ekonomileri örneği. Eskişehir Osmangazi Üniversitesi İ̈BF Dergisi, 12(1), 121-140.

Sarıbaş, E. (2015). Türkiye'deki enerji kaynaklar ve įlenen enerji politikalar (Yüksek Lisans Tezi). Niğde Üniversitesi, Sosyal Bilimler Enstitüsü, Niğde.

Schumpeter, J. A. (1911). The theory of economic development. Cambridge, MA: Harvard University Press.

Shahbaz, M., Abosedra, S. ve Sbia, R. (2013). Energy consumption, financial development and growth: Evidence from cointegration with unknown structural breaks in Lebanon. Munich Personal RePEc Archive, MPRA Paper No. 46580.

Shaw, E. (1973). Financial deepening in economic development. New York: Oxford University Press.

Sinha, A. ve Bhatt, M. Y. (2017). Environmental Kuznets curve for CO2and NOx emissions: A Case Study of India. European Journal of Sustainable Development, 6(1), 267-276.

Smith, A. (1776). An inquiry into the nature and causes of the wealth of nations. Erişim adresi: https://www.earlymoderntexts.com/assets/pdfs/smith1776_1.pdf, Erişim Tarihi: 22.06.2019.

Solarin, S. A., Shahbaz, M., Khan, H. N. ve Razali, R. B. (2019). ICT, financial development, economic growth and electricity consumption: New evidence from Malaysia. Global Business Review, 1-22

Solow, R. (1956). A contribution to the theory of economic growth. Quarterly Journal of Economics, 70(1), 65-94.

Stock, J. ve Watson, M. W. (1993). A simple estimator of cointegrating vectors in higher order integrated systems. Econometrica, 61(4), 783-820.

Swan, T. (1956). Economic growth and capital accumulation. Economic Record, 32(63), 334-361.

Şamiloğlu, F. (2007). Türkiye’nin güclü ekonomiye geçis program üzerine bir değerlendirme. Erişim adresi: http://archive.ismmmo.org.tr/docs/malicozum/55MaliCozum/10\%20-\%2055\%20FAMILSAMILOGLU.doc, Erişim Tarihi: 21.06.2019.

Şentürk, İ. (2012). Kaynaklarna göre enerji tüketiminin ekonomik büyümeye etkileri (Doktora Tezi). Hacettepe Üniversitesi Sosyal Bilimler Enstitüsü, Ankara.

Taban, S. (2010). İktisadi büyüme kavram ve modeller. Eskişehir: Nobel Yayıncılık.

Taban, S. ve Kar, M. (2016). Kalkinma ekonomisi. Bursa: Ekin Yayınevi.

TBB (2019a). Istatistiki raporlar, seçilmiş istatistikler, 2018-Banka gruplar baẓnda mevduat ve keredi dağılımı, Erişim adresi: https://www.tbb.org.tr/tr/bankacilik/banka-ve-sektor-bilgileri/istatistiki-raporlar/59, Erişim Tarihi: 15.10.2019.

TBB (2019b). İstatistiki raporlar, seçilmiş istatistikler, banka, çalsan ve şube bilgileri, Erişim adresi: https://www.tbb.org.tr/tr/bankacilik/banka-ve-sektor-bilgileri/istatistiki-raporlar/59, Erişim Tarihi: 15.10.2019.

TCMB (2015a). Türkiye'de finansal istikrar gelismeleri. Ankara: Türkiye Cumhuriyet Merkez Bankası yayınları.

Tiryakioğlu, M. (2006). Araștırma-geliştirme ekonomike büyüme iliskeisi: Seçilmis OECD ülkeleri üzerine uygulama (Yüksek Lisans Tezi). Afyon Kocatepe Üniversitesi, Sosyal Bilimler Enstitüsü, Afyon

Torun, İ. (2003). Endüstri toplumunun oluşmasında etkili olan iktisadi ve sina-i faktörler. C.Ü. İktisadi ve İdari Bilimler Dergisi, 4(1), 181-196.

Tutgun, S. (2019). Türkiye'de finansal gelişme ve enerji tüketiminin ekonomik büyüme üzerindeki etkisi: ARDL sınır testi yaklaşımı. Bitlis Eren Üniversitesi Akademik İzdüsü̈m Dergisi, 4(1), 50-65.

Uslu, H. (2018). Enerji tüketimi ve ekonomik büyüme ilişkisi: Gelişmekte olan ülkeler üzerine panel veri analizi. Journal of Social And Humanities Sciences Research (JSHSR), 15(20), 729-744.

Vogelsang, T. J. (1993). Unpublished Computer Program.

Vogelsang, T. J. ve Perron, P. (1998). Additional test for unit root allowing for a break in the trend function at an unknown time. International Economic Review, 39, 1073-1100.

World Bank (2019d). GDP (current US\$). Erişim adresi: https://data.worldbank.org/indicator/ NY.GDP.MKTP.CD?view= chart, Erişim tarihi: 15.10.2019.

World Bank (2019e). Energy use ( $\mathrm{kg}$ of oil equivalent per capita). Erişim adresi: https://data.worldbank.org/indicator/EG.USE.PCAP.KG.OE?view=chart, Erişim Tarihi: 24.10.2019.

World Bank (2019f). Population, total. Erişim adresi: https://data.worldbank.org/ indicator/SP.POP.TOTL, Erişim Tarihi: 24.10.2019.

World Bank (2019g). Energy imports, net (\% of energy use), Erişim adresi: https://data.worldbank.org/indicator/EG.IMP.CONS.ZS?view=chart Erişim Tarihi: 24.10.2019.

World Bank (2019i). GDP per capita (constant 2010 US\$). Erişim adresi: https://data.worldbank.org/indicator/NY.GDP.PCAP.KD?view=chart, Erişim Tarihi: 26.10.2019.

Yağlı, İ. ve Topçu, E. (2019). Finansal gelişme ve ekonomik büyüme arasındaki nedensellik ilişkisi: G7 ülkeleri örneği. Afyon Kocatepe Üniversitesi Sosyal Bilimler Dergisi, 21(3), 888-898.

Yamak, T. (2006). Türkiye'nin alternatif enerji kaynaklar potansiyeli ve ekonomik analiðleri (Yüksek Lisans Tezi). Marmara Üniversitesi, Sosyal bilimler Enstitüsü, İstanbul.

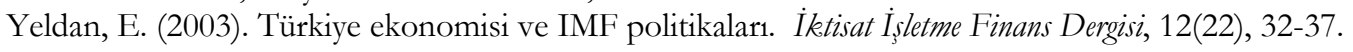


Yeldan, E. (2009). Kapitalizmin yeniden finansallaşması ve 2007/2008 krizi: Türkiye krizin neresinde? Calışma ve Toplum, 1, 11-28.

Yıldız Contuk, F. (2015). Finansal piyasalardaki gelismelerin ekonomik büyüme üzerine etkileri: 1998-2014 Türkiye örneği (Doktora Tezi). Atatürk Üniversitesi, Sosyal Bilimler Enstitüsü, İşletme Anabilim Dalı, Erzurum.

Yülek, M. A. (1997). İçsel büyüme teorileri, gelişmekte olan ülkeler ve kamu politikaları üzerine. Hað̧ine Dergisi, 6, 89103.

\section{EXTENDED ABSTRACT}

Achieving and sustaining economic growth is one of the most important priorities of all countries. For this purpose, countries have made new geographical discoveries, carried out colonial activities, made wars, peace, agreements, experienced industrial revolutions and social transformations. In this process, scientists have also made intensive efforts to identify the sources and ways of sustainable economic growth, to test the effectiveness of the implemented policies in this way, and to develop suggestions for the elimination of the problems they can identify.

For a sustainable and high economic growth process, it is of great importance that countries are financially developed and that they can access the necessary energy resources uninterruptedly and at affordable costs. Today, bilateral cooperation agreements signed between countries, economic and political integrations established, and distinctions from certain integrations, as in the case of England, are all aimed at maximizing economic benefit.

In this study, the effects of financial development and energy consumption on economic growth have been analyzed using annual data for the 1960-2019 period. The stationarity of the series, Vogelsang and Perron (1998), Lee and Strazicich (2003) and Carrion-i-Silvestre et al. (2009) were analyzed using unit root tests with structural break and all series were determined to be I (1). Existence of cointegration relationship between series in models; Gregory and Hansen (1996) and Maki (2012) examined with structural break cointegration tests and it was decided that there was a cointegration relationship between the variables in the models. In other words, these series act together and no spurious regression problem will be encountered in the analysis to be made using the level values of these series. The structural break dates determined in the Maki (2012) cointegration test with multiple structural break were included in the dummy variables in the long and short term analyzes.

Long term analysis was carried out with FMOLS, DOLS and CCR methods. As a result of these analyzes, it was determined that economic growth increased by $0.13 \%$ on average when the loan amount used by the private sector increased by $1 \%$, between $0.13 \%$ and $0.24 \%$ when the money supply increased by $1 \%$, and by $0.40 \%$ when energy consumption increased by $1 \%$. According to these results, in1960-2019 period, there were economic growth, the most effective factor; energy consumption in Turkey. It was followed by money supply and private sector loans. In the study, short-term analyzes were carried out within the framework of error correction model, again with FMOLS, DOLS and CCR methods. As a result of these analyzes, it has been determined that loans increase economic growth in the short run, but this effect is smaller than in the long run. It has been observed that the short-term effects of the increases in the money supply on the economic growth are positive and smaller than that in the long run. Energy consumption, on the other hand, has been found to affect economic growth more in the short run than in the long run. The coefficients of the error correction terms of the models were found to be negative and statistically significant. Based on this result, it was decided that the error correction mechanisms of the models were working and the analyzes made were reliable. The fact that the long and short term analyzes of the study were carried out using all three FMOLS, DOLS and CCR methods made the study stronger by allowing all details to be taken into account. Because it has been possible to reveal an effect that cannot be determined by one method by using another method.

Since the series used in the study are stationary in the first difference and the cointegration relationship between them was also determined, the causality relationships between them were analyzed by VECM method. According to this, the energy consumption of the 1960-2019 period, economic growth in Turkey and the money supply in the one-way, from loan volume energy consumption and money supply on the one-way, between the energy consumption of the money supply has been found to have two-way long-term causal relationship. On the other hand, in 1960-2019 period, it has been determined that the volume of loans in Turkey is the only correct way to energy consumption, energy consumption, with money from symptoms and that there is a short period of bi-directional causality. The findings obtained 
from this analysis are in the literature; Aytaç (2010); Ndlovu (2013); Rezitis and Ahammad (2015); It is consistent with the findings of Magazzino (2016) and Akhtar, Sheikh and Altaf (2016) studies.

Based on the findings obtained from this study, it can be said that loans to the private sector, monetary expansion and energy consumption increase economic growth, the long-term effects of loans and monetary expansion to the private sector and the short-term effects of energy consumption are greater. Therefore, in order to steadily increase the economic growth of the country. It is considered that it would be beneficial for households and companies to try to provide access to cheap and safe energy by giving importance to monetary expansion on the one hand, facilitating access to loans by the private sector, and improving energy production and transmission in the country on the other. But, it should not be forgotten that monetary expansion may cause inflation, as Friedman stated, and this policy should be applied for a short period of time, perhaps during periods of economic recession. Today, because of the outbreak in Turkey and the world Covidien-19 in this frame of monetary stimulus policies implemented across, there are benefits for the careful execution. On the other hand, while facilitating the use of loans by the private sector, risky transactions that could put the financial system in a difficult position should be avoided, and macro prudential policies implemented since 2012 should not be compromised. 